On the biology of Gyrodactylus spp. and their hosts in natural and human influenced freshwater systems

By Ruben Alexander Pettersen

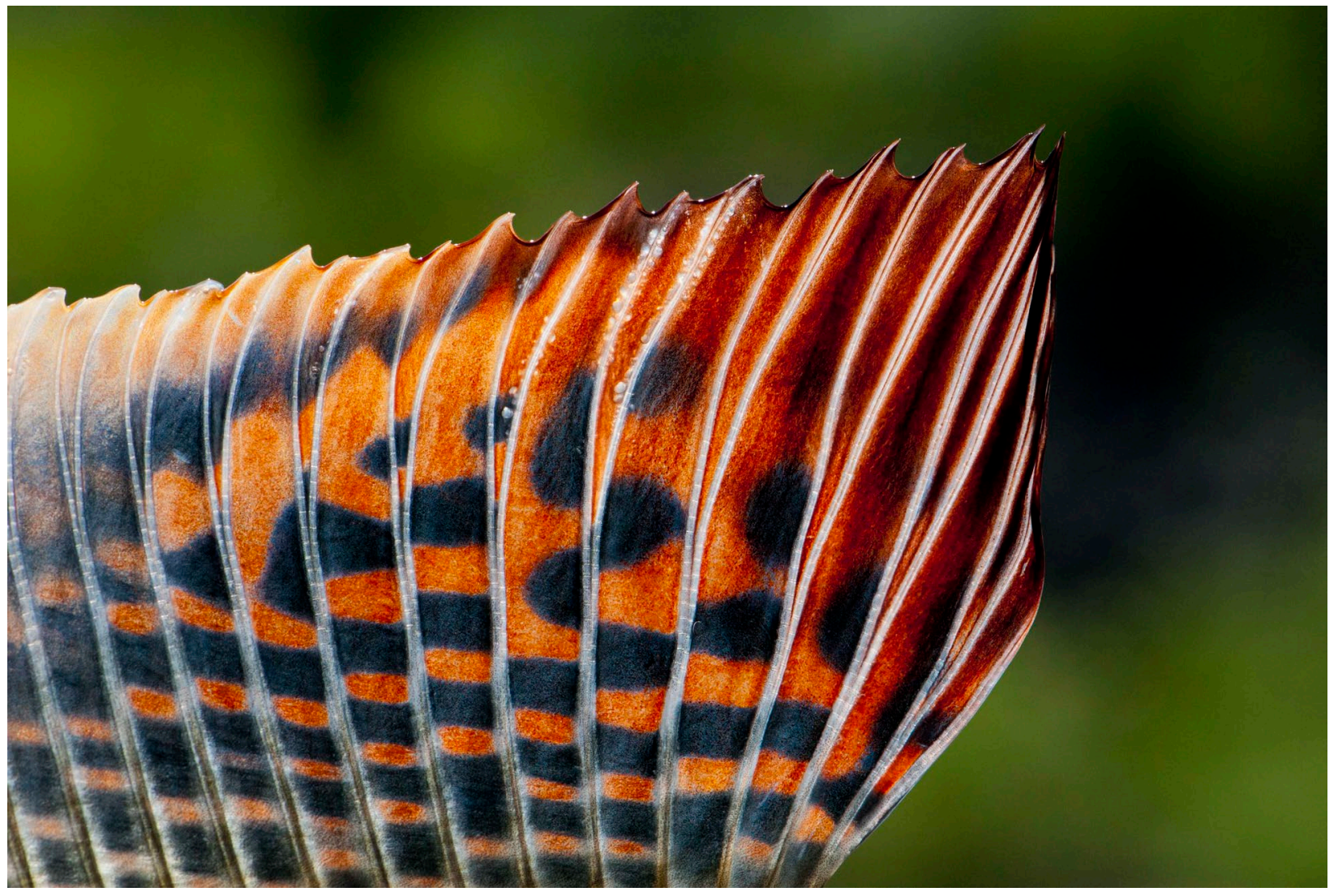


(C) Ruben Alexander Pettersen, 2018

Series of dissertations submitted to the Faculty of Mathematics and Natural Sciences, University of Oslo No. 2030

ISSN 1501-7710

All rights reserved. No part of this publication may be reproduced or transmitted, in any form or by any means, without permission.

Cover: Hanne Baadsgaard Utigard.

Print production: Reprosentralen, University of Oslo. 


\section{CONTENTS}

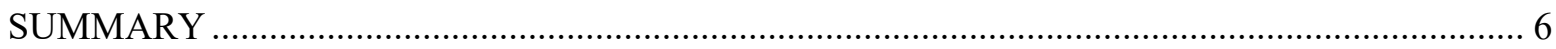

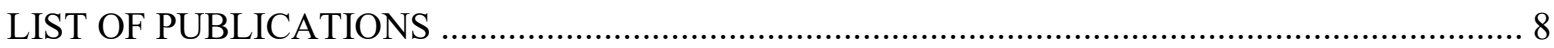

INTRODUCTION

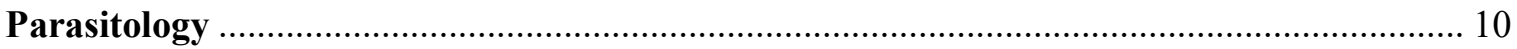

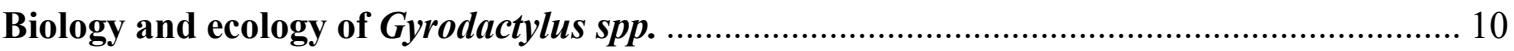

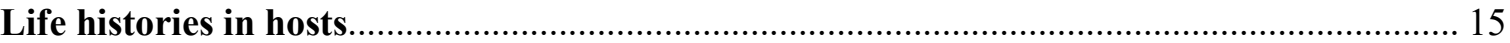

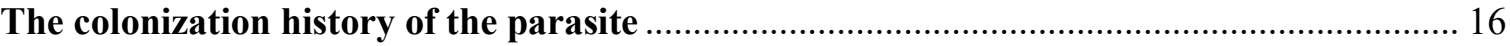

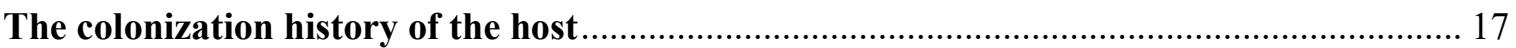

Translocated fish hosts and the dispersal of Gyrodactylus spp. communities......................... 18

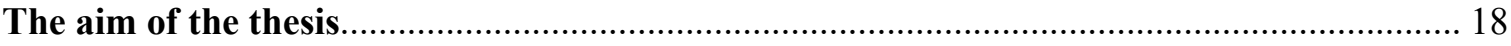

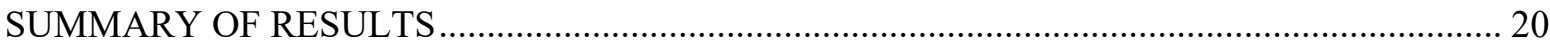

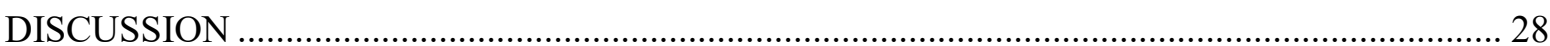

Natural dispersal of Gyrodactylus spp. on grayling and minnow hosts across space and

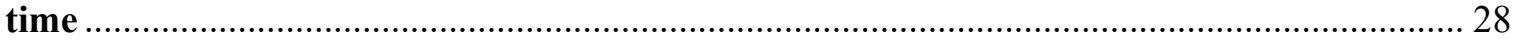

Translocated fish hosts, minnow and salmon, and the dispersal of Gyrodactylus spp.

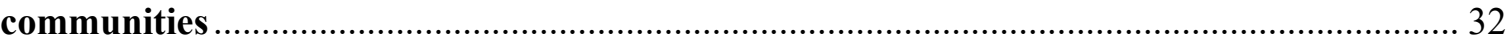

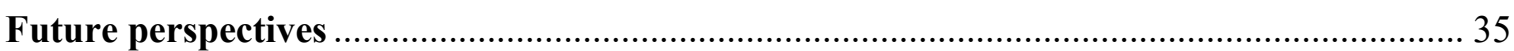

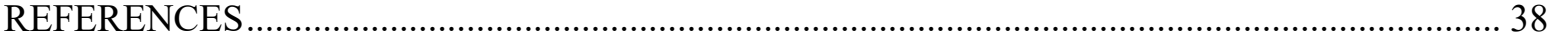





\section{Preface}

At the very first, I have to admit one thing: I am an avid fisherman. In the same year I got my first brown trout (Salmo trutta L.) on a dry fly, I started to read newspapers. An article that made a strong impression on me was «The Salmon killer». There was a picture of Gyrodactylus salaris, and a description of what a fish parasite was. At that time, I did not know, that Tor Atle Mo had taken this picture, and that he would be my main supervisor for this thesis. Later, I took a trip to the library to find out what this was all about. I really remember the discussions between old anglers if $G$. salaris could infect our Salmon River Glomma. I had already spent many hours working with the cultivation of this Atlantic salmon (Salmo salar L.) stock in River Glomma and felt that this work could be in vain. My interest in fish and parasites led me to graduate at the University of Oslo on fish parasites and water quality. With this in my luggage, I got a position at the Veterinary Institute (VI) to find a new method to kill G. salaris where we used aquatic aluminium added into to the river. Five years later, I wanted other challenges, and started in a PhD Research Fellowships at University of Oslo. This was a university fellow position with a high degree of freedom, but very little resources for activities. Therefore, this thesis has been made up of many different projects, dependent on materials and opportunities. Atlantic salmon in River Glomma have not been infected with G. salaris, but I have found its close relative G. thymalli on grayling (Thymallus thymallus (L.)) in my childhood river (Paper I). For this is precisely what this thesis is about: Man's management of nature and the consequences this can lead to in an academic context. 



\section{Acknowledgements}

I would like to thank my supervisor Tor Atle Mo for your positivity and I appreciate that you are so open to new thoughts in discussions with common subjects. I have learned a lot of parasitology from you. Also, Asbjørn Vøllestad for your help and support more or less on a daily basis throughout my period as a PhD student, you are always open for questions. Kjartan Østbye, as a good friend and colleague, you have meant a lot to me with your helpfulness and for academic discussions. If not for the minnow man Johannes Holmen, there would have been no Paper III, thank you for your helpfulness. Haakon Hansen, Sigurd Hytterød and Claudia Junge, thank you for your cooperation, fruitful discussions and for being great co-workers on the papers. I am grateful to Ole Haakon Heier, Jan Teigen, Erik Lien, Finn Gregersen and Henning Pavels for their assistance during sampling of grayling.

I would like to express my very great appreciation to Odd Halvorsen, who made me a parasitologist. There has been a lot of discussion over a cup of coffee in the parasite lab (which is otherwise illegal) at Natural History Museum. Anders Nielsen my next-door office discussion partner about malt, hops, flowers and bee(r)s, I'm grateful for your daily basis shit chat. I will also like to thank Dimitar Serbezov for being the ultimate office-mate and a good teacher in population genetics.

I would also like to thank all the people from the section for Parasitology on Veterinary Institute and the people from CEES lab for all their help during the lab work. Nanna Winger Steen and Emelita Rivera Nerli are acknowledged for their technical assistance in the laboratory. I would like to thank you all at CEES, for the good conversations around the water holes (coffee machines) at the corner rooms.

Last, but not least, I would like to thank my parents Øystein and Sidsel, my brother Markus, my sister Tonje and mother in law Grethe for all the support I have received through the years. I am particularly appreciative to my wife Camilla for enduring with me through the years. I also especially thankful for my daughter Ingrid Linnèa patience, who has all her life, heard that; dad is working on his doctorate. Thank you for being there for me in this bumpy road to become a doctor. Finally, we will appreciate to be more together with you in weekends and holidays in the future.

I thank the University of Oslo for all the support during the implementation. I would like to thank the Research Council of Norway (RCN) and the Norwegian Directorate for Nature Management (DN), for the grant to collect minnows and conduct genetic analysis. I would also like to thank the VI for the use of their labs and facilities without taking bench fee. I would also thank the RCN for the grant to perform genetic analysis on grayling. Finally, I would like to thank the following endowments that I have received grant from; Professor Rathke, Professor R. Collett, Professor N. Willes legat, and Professor S. A. Sexes legat. 



\section{SUMMARY}

In this thesis, I studied Gyrodactylus (Monogenea) parasites in natural and human influenced fish populations to better understand the dispersal mechanisms of Gyrodactylus species and their hosts. I also wanted to explore how the genetic diversity of the parasite might be linked to the genetic variation of the host in a number of different populations. I used two different parts of the mitochondrial (mt) dehydrogenase subunit 5 (NADH 5) and the cytochrome oxidase I (COI) genes to describe genetic population structure of G. thymalli Žitňan, 1960, an ectoparasite of European grayling (Thymallus thymallus (L.)), ${ }^{1}$ throughout the largest watercourse in Norway (Paper I). Three main clusters of haplotypes dominated in three distinct geographic parts of the river system. A positive correlation between pairwise genetic distance and hydrographic distance between populations was found (isolation by distance - IBD). To answer how genetic diversity might be linked to the genetic variation of the host, I studied population genetic structure of grayling populations using microsatellites, and compared them to the NADH5 gene data from $G$. thymalli populations in Lake Mjøsa. This lake is a smaller part of the River Glomma system, without barriers to gene flow (Paper II). There was a nonsignificant population genetic pattern between G. thymalli and its host. Most of the molecular variance for G. thymalli and grayling was detected within the tributaries. The individual behavior of grayling may lead to random transmission of parasites.

Translocation of native species, and introduction of alien and invading species are potentially harmful to the local biota. The enemy release hypothesis (ERH) states that host populations lose parasites during translocation to new environments. This hypothesis was addressed in Paper III. Differences in species community and the load of Gyrodactylus ectoparasites were investigated in 14 native and 29 translocated minnow (Phoxinus phoxinus L.) populations in Norway. Host heterozygosity was used as a covariate. The results showed that native and introduced minnow populations had similar species compositions of Gyrodactylus, leaving no support for the ERH. The two minnow groups did not differ in the likelihood of being infected with Gyrodactylus. Here, the more homozygotic minnows had higher Gyrodactylus infections than more heterozygotic hosts. Another introduced and invading species is G. salaris Malmberg, 1957, which infects the skin and fins of Atlantic salmon (Salmo salar L.) leading to serious physical injury or mortality. The pathogenesis of G. salaris was examined among experimentally infected Atlantic salmon parr (age 0+). An sets of physiological blood parameters were measured (Paper IV). All fish from the infected group showed a distinct loss of serum ions, leading to the conclusion that a heavy G. salaris infection causes osmoregulatory failure and stress, causing mortality in Atlantic salmon juveniles.

\footnotetext{
${ }^{1}$ Cover photo of the dorsal fin of a European grayling (Thymallus thymallus (L.)) Photo: Ruben A. Pettersen
} 
In conclusion, I found large genetic diversity for the G. thymalli infecting its grayling host in the large Glomma river system, where barriers to migration and long distances have led to IBD genetic structure. In the smaller systems of Lake Mjøsa, where there are no barriers to migration, there was only very weak genetic structure in G. thymalli and no evidence for IBD. There was covariation in the genetic population structure of the parasite and its host in this system. Further, I did not find any support for ERH, when compering native and introduced minnow populations, however the native populations had a higher number of Gyrodactylus individuals per host, than introduced populations. Lastly, an extreme infection of G. salaris on Atlantic salmon parr penetrating the skin leads to loss of ions and results in sudden death of the host. 


\section{LIST OF PUBLICATIONS}

Paper I. Pettersen R. A., Mo T. A., Hansen H. \& Vøllestad L. A. (2015). Genetic population structure of Gyrodactylus thymalli (Monogenea) in a large Norwegian river system. Parasitology 142: 1693-1702.

Paper II. Pettersen R. A., Junge C., Østbye K., Mo T. A. \& Vøllestad L. A. Genetic population structure of the monogenean parasite Gyrodactylus thymalli and its host European grayling (Thymallus thymallus) in a large Norwegian lake. Manuscript.

Paper III. Pettersen R. A., Østbye K., Holmen J., Vøllestad L. A. \& Mo T. A. (2016). Gyrodactylus spp. diversity in native and introduced minnow (Phoxinus phoxinus) populations: no support for "the enemy release" hypothesis. Parasites and Vectors 9: 51.

Paper IV. Pettersen R. A., Hytterød S., Vøllestad L. A. \& Mo T. A. (2013). Osmoregulatory disturbances in Atlantic salmon, Salmo salar L., caused by the monogenean Gyrodactylus salaris. Journal of Fish Diseases 36: 67-70.

Quote:

"For real progress, the modeller as well as the epidemiologist must have mud on their boots" (David Bradley, 1982) 


\section{INTRODUCTION}

\section{Parasitology}

Parasitology is the scientific study of interactions between parasites and hosts, the co-evolution of their life histories, dispersal, and their responses to the abiotic and biotic environment (review by Bozick \& Real 2015). Parasites may be internally living as endoparasites or living externally on their hosts as ectoparasites. Their life histories may vary from being strictly host specific to being generalists having multiple host species. Some parasites have a direct life cycle without an intermediate host, while other parasites can have several intermediate hosts prior to their main host.

A long history of co-occurrence of parasite and host may lead to tight co-evolution, whereas the response of a host that has only recently been exposed to a new parasite may be unpredictable (Woolhouse et al., 2002). Thus, the response of the host to a parasite infection can vary from no apparent negative fitness consequences to pathogenicity. The study of parasite population dynamics has often been associated with large epidemiological impacts on humans, where the focus has been to study the spread of the disease in host populations (Anderson, 1982; Woolhouse et al., 2005). Monogenean ectoparasites are an ideal model organism for studying host-parasite interactions and dispersal as they lack intermediate hosts and have short generation times (Poulin, 2007; Bakke et al., 2007). These are all traits that render these organisms very useful for studies of natural host-parasite systems, and for describing host pathogenesis under controlled laboratory experiments (Poulin, 2007). However, in general, we still lack knowledge regarding interactions of host and parasites in natural systems (Poulin, 2007).

\section{Biology and ecology of Gyrodactylus spp.}

The Class Monogenea is one of the most species-rich groups of ectoparasites (Poulin \& Morand, 2004). Within this class, the genus Gyrodactylus was first described by von Nordmann in 1832. A recent estimate suggests approximately 20,000 existing species within this genus where just a few are reported as pathogenic (Bakke et al., 2002, 2007; Harris et al., 2004). Gyrodactylus species are characterized by having a direct life cycle, short generation time, and rapid population growth. They most often infect the skin and fins of fish, though some species prefer the gills of fish. A viviparous life history strategy allows Gyrodactylus to directly transfer between hosts at any stage of its life cycle (von Sieboldt, 1849). Gyrodactylus has lost the swimming oncomiracidium ciliated larva stage that characterizes the Monogeneans (Harris, 1983). When attached to their host, Gyrodactylus species cause at least two types of physical damage to the host's epidermis as a result of their feeding activity and their attachment organ (El Nagar \& MacColl, 2016). Harris (1983) recorded feeding by $G$. gasterostei Gläser 1974 at a frequency of every 15-30 minutes with feeding wounds 20-30 $\mu \mathrm{m}$ in 
diameter. In addition, the epidermis can be damaged by the 16 marginal hooks and two central anchors in the opisthaptor (the attachment organ), potentially leaving 16 shallow and two deeper holes in the skin (Lester, 1972) (Figure 1). In teleost fish, the skin is known to play an important role as an osmotic barrier (Evans, 1993). Thus, Gyrodactylus induced damage to the epidermis could lead to osmoregulatory failure.

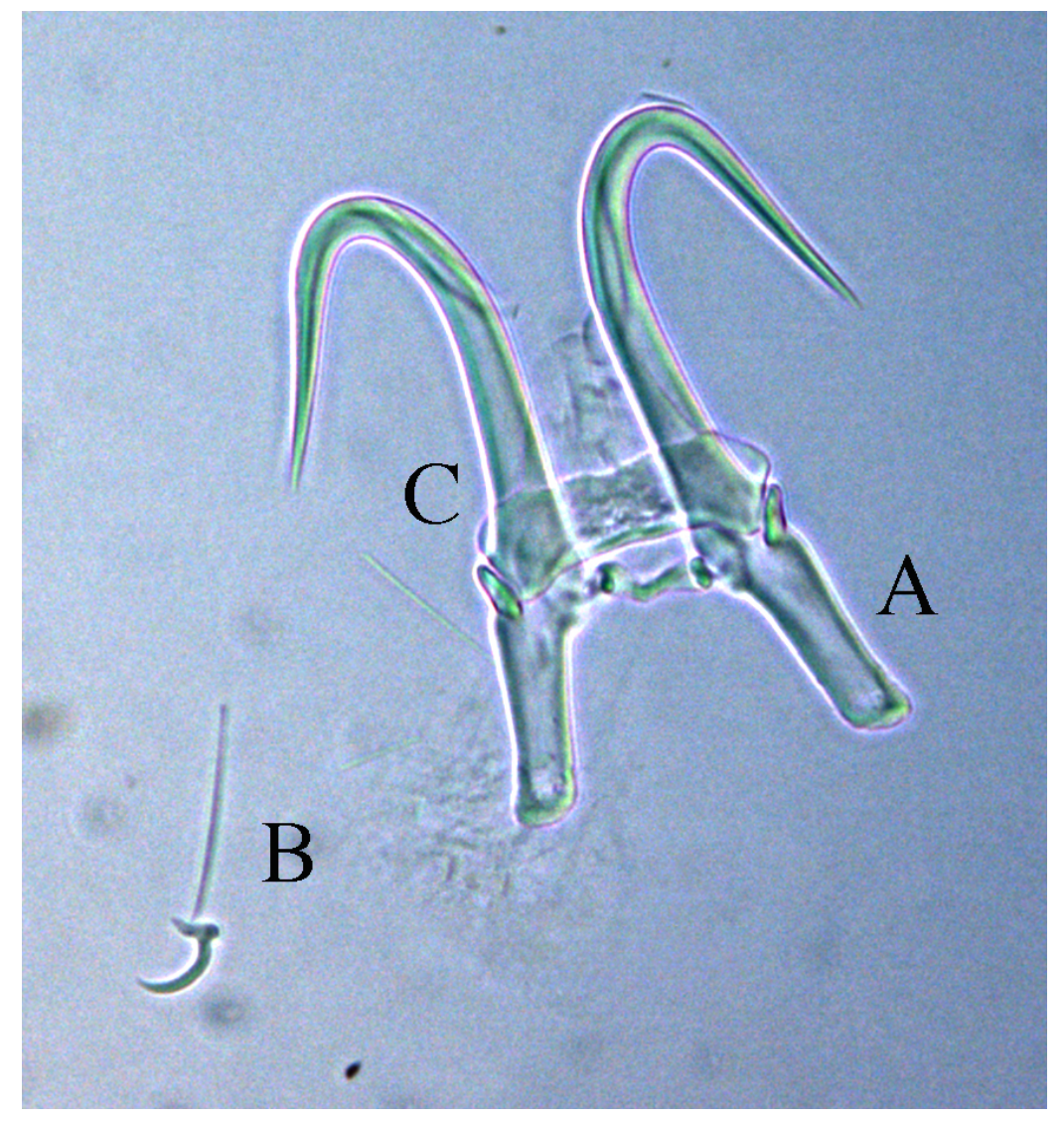

Figure 1. Gyrodactylus macronychus opisthaptoral hard parts. Photo: Ruben A. Pettersen. Pictured are the haptoral hard parts used to identify Gyrodactylus species (Buchmann \& Uldal, 1997; Mo \& Appleby, 1990). Opisthaptoral hard-parts depicted after digestion of all soft tissue are A: hamulus, B: marginal hook and C: ventral bar. Proteinase K ( $1 \%$ in buffer) was used to remove the tissue around the haptoral hard parts. The haptoral hard parts were then mounted on a microscope slide in formaldehyde-glycerine (15:85) fixative. For visualization of haptoral hard parts, a Leica DM $4000 \mathrm{~B}$ microscope with a Heine phase contrast condenser, and a 100X/1.25 oil immersion objective was used (see Buchmann \& Urdal 1997). The microscope was linked to a Leica DFC 320 digital camera and archiving system. A computer with Leica software LAS $\odot$ was used to take pictures for future analysis of measurements.

One of the well-studied Gyrodactylus species is G. salaris Malmberg 1957. In 1975, G. salaris was observed on wild Atlantic salmon (Salmo salar L.) parr from Lakselva and Ranaelva rivers in Northern Norway (Johnsen, 1999; Johnsen \& Jensen, 1986). Since then, the parasite has been further recorded in 50 Norwegian wild salmon rivers, 13 hatcheries with salmon parr and 26 hatcheries with rainbow trout (Oncorhynchus mykiss Walbaum, 1792) (Forseth et al., 2017; Hytterød et al., 2014). In addition, G. salaris also occurs in 16 rivers on the Swedish west coast and in several rainbow trout farms and 
salmon hatcheries throughout Fennoscandia (Hytterød et al., 2014; Malmberg \& Malmberg, 1993), and in Europe (Dzika et al., 2009; Hansen et al., 2016; Paladini et al., 2009; Rokicka et al., 2007). In all of the wild Atlantic salmon populations in Norway, the parasite has resulted in a considerable decline in the salmon parr density (approximately 50\%) within two years after introduction, increasing to declines of $86 \%$ five to seven years after the introduction (Johnsen \& Jensen, 1986, 1991). In the Baltic Basin, salmon populations are considered resistant to G. salaris, because G. salaris is believed to be an endemic parasite to the Baltic Basin (Anttila et al., 2008; Ieshko et al., 2016; Lumme et al., 2016). G. salaris has also been reported on Arctic charr, (Salvelinus alpinus L.), brown trout (Salmo trutta L.), brook trout, (Salvelinus fontinalis (Mitchill, 1814)), and lake trout (Salvelinus namaycush (Walbaum, 1792)). In these cases, the host has a response to the parasite and G. salaris causes less damage (Olstad et al., 2007; Paladini et al., 2009, 2015; Robertsen et al., 2007; Sterud et al., 1998). Non-pathogenic strains of G. salaris have also been reported beyond the Baltic Basin (Kania et al., 2007; Olstad et al., 2007). Today, G. salaris is one of the major threats to Atlantic salmon in Norway, but has been evaluated as having a low likelihood of causing further population loss (Forseth et al., 2017).

A very closely related species to G. salaris is G. thymalli Žitňan (1960). G. thymalli was first described on wild grayling (Thymallus thymallus (L.)). Unlike G. salaris, G. thymalli seems to have no major negative consequences for grayling in contrast to G. salaris on Atlantic salmon (Sterud et al., 2002). Today, G. thymalli is widespread throughout Eurasia, but was certainly restricted to different ice lake refugia during the last glacial maximum (LGM) giving rise to at least four major mtDNA lineages (Hansen et al., 2003, 2006, 2007b; Kuusela et al., 2009; Lindqvist et al., 2007). Several phylogenetic lineages and haplotypes of $G$. thymalli have been found in European rivers and numerous mitochondrial haplotypes of $G$. thymalli, grouping to more than ten well-supported clades, have been identified from Scandinavian, British, and Central European localities (Hansen et al. 2003, 2006, 2007a, b,; Lindqvist et al., 2007; Kuusela et al., 2009). Unfortunately, the basal nodes linking the clades together are only weakly supported.

There is ongoing taxonomic discussion as to whether G. thymalli and G. salaris are one or two species. G. thymalli on grayling is morphologically and genetically very similar to G. salaris (Meinilä et al. 2004; Olstad et al. 2007, 2009). In this context, different molecular markers have traditionally been used for identification and discrimination of these two species (Cunningham et al., 2001; Hansen et al., 2007b; Ziętara et al., 2002). However, none of these markers support the separate species status of $G$. salaris and G. thymalli. Further, a study of genetic differentiation in microRNA in several populations of $G$. salaris and $G$. thymalli conclude that the traditional species concept used for $G$. salaris and G. thymalli does not reflect a meaningful system to describe their taxonomic status (Bachmann et al., 2016; Fromm et al., 2014). These authors suggest that G. salaris and G. thymalli is 
a single species that consists of several pathogenic and non-pathogenic strains residing on various primary hosts. Thus, G. thymalli has been proposed as a junior synonym of G. salaris (Kuusela et al., 2007; Meinilä et al., 2004). However, Fromm et al., (2014) did not include specimens from the type localities for these two species, which should ideally be used when synonymizing species according to the nomenclatural concept of the International Code of Zoological Nomenclature (ICZN ${ }^{2}$ ). Despite the findings by Fromm et al., (2014), experiments have documented that G. thymalli is not able to survive on Atlantic salmon while G. salaris cannot survive on grayling (Sterud et al. 2002). Thus, there are clear biological differences between the two species. G. thymalli seems to be the only Gyrodactylus species parasitizing grayling to a large degree (Hansen et al., 2007a) while G. salaris has the ability to complete its life cycle on different fish species (Bakke et al. 2007) - which adds complexity to their evolutionary history. This debate is still ongoing however, since the G. salaris / G. thymalli species complex has not been evaluated according to the nomenclatural concept (ICZN) when integrating genetic markers, biology and morphology. Therefore, in this thesis, I have chosen to use the separate species names, referring to G. thymalli for parasites from T. thymallus only, and to $G$. salaris for Gyrodactylus species from other hosts (Atlantic salmon, Arctic charr, rainbow trout).

Other fish species are known to be hosts of several Gyrodactylus species. The European minnow (Phoxinus phoxinus L.) is host to more than one Gyrodactylus species, making the minnow a suitable candidate for studies of species diversity of Gyrodactylus. Several species of Gyrodactylus have previously been reported on minnows from Norway: G. laevis, Malmberg 1957, G. magnificus Malmberg, 1957, G. phoxini Malmberg, 1957, G. macronychus Malmberg, 1957, G. aphyae Malmberg, 1957 (Sterud, 1999). I found only four of these species (Figure 2) in an extensive survey throughout Norway (Paper III). Further, nine different Gyrodactylus species have been reported on minnow elsewhere in Eurasia ${ }^{3}$ (Harris et al., 2008; Dorovskikh \& Stepanov, 2008; Matějusová et al., 2000).

\footnotetext{
2 www.iczn.org

3 www.gyrodb.net
} 


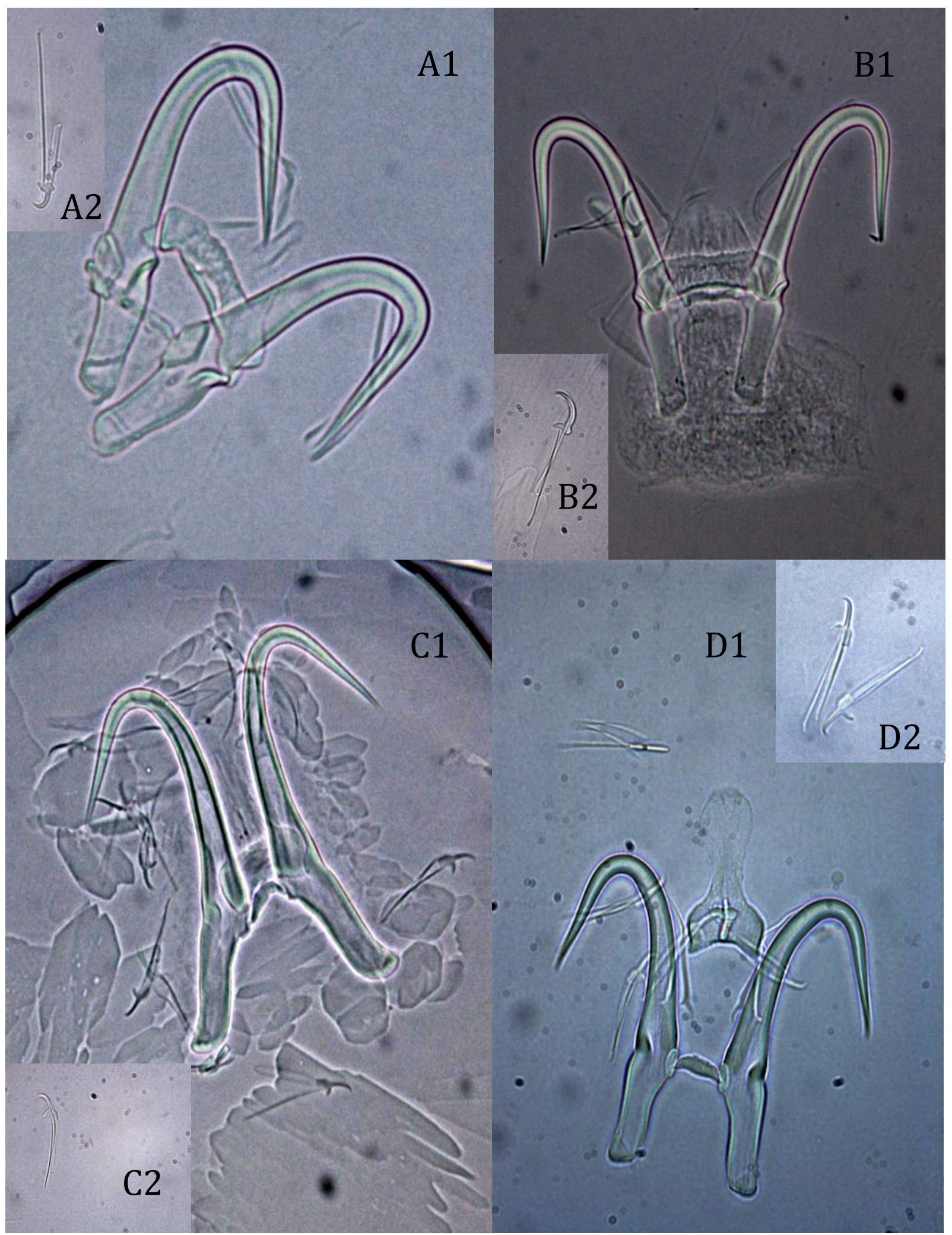

Figure 2. Photographs of the opisthaptoral hard parts from Gyrodactylus spp., which parasitizes minnow (Phoxinus phoxinus). Photo: Ruben A. Pettersen. The figure shows hamulus (A1) and marginal hook (A2) of G. aphye, G. macronycus (B1 and B2), G. magnificus (C1 and C2) and G. phoxini (D1 and D2) as found in Paper III. Note that there are different scales on the pictures. See figure 1 for methods. 


\section{Life histories in hosts}

Parasites with a direct life cycle are dependent on their host and have the same distribution as their host (review by Bozick \& Real, 2015). Thus, the host life history is also important for the parasite's life cycle. Grayling spawn during early spring, at which time they migrate from lakes or large rivers to spawning areas in smaller tributaries (Northcote, 1995). During spawning male grayling hold and defend spawning territories (Beauchamp, 1990). After spawning all mature fish return to the lakes or rivers (Northcote, 1995). It is during the period of aggregation and spawning, when individuals will be close together, that Gyrodactylus transmission may be most common compared to the rest of the life cycle (Pickering \& Christie, 1980; Richards et al., 2012). Grayling embryos hatch in June and the juveniles may stay in the tributaries until September (Kristiansen \& Døving, 1996). The generations of grayling in small tributaries have no overlap in their habitat, which means that transmission between generations is absent. Mature grayling return to spawn in the same tributaries or same areas in rivers year after year, indicating some level of reproductive isolation between grayling from different tributaries or areas in rivers (Kristiansen \& Døving, 1996; Northcote, 1995). This spawning behaviour combined with local variation and adaptations in various life history traits suggest that grayling populations are genetically differentiated (Gregersen et al., 2008; Haugen \& Vøllestad, 2000; Junge et al., 2011).

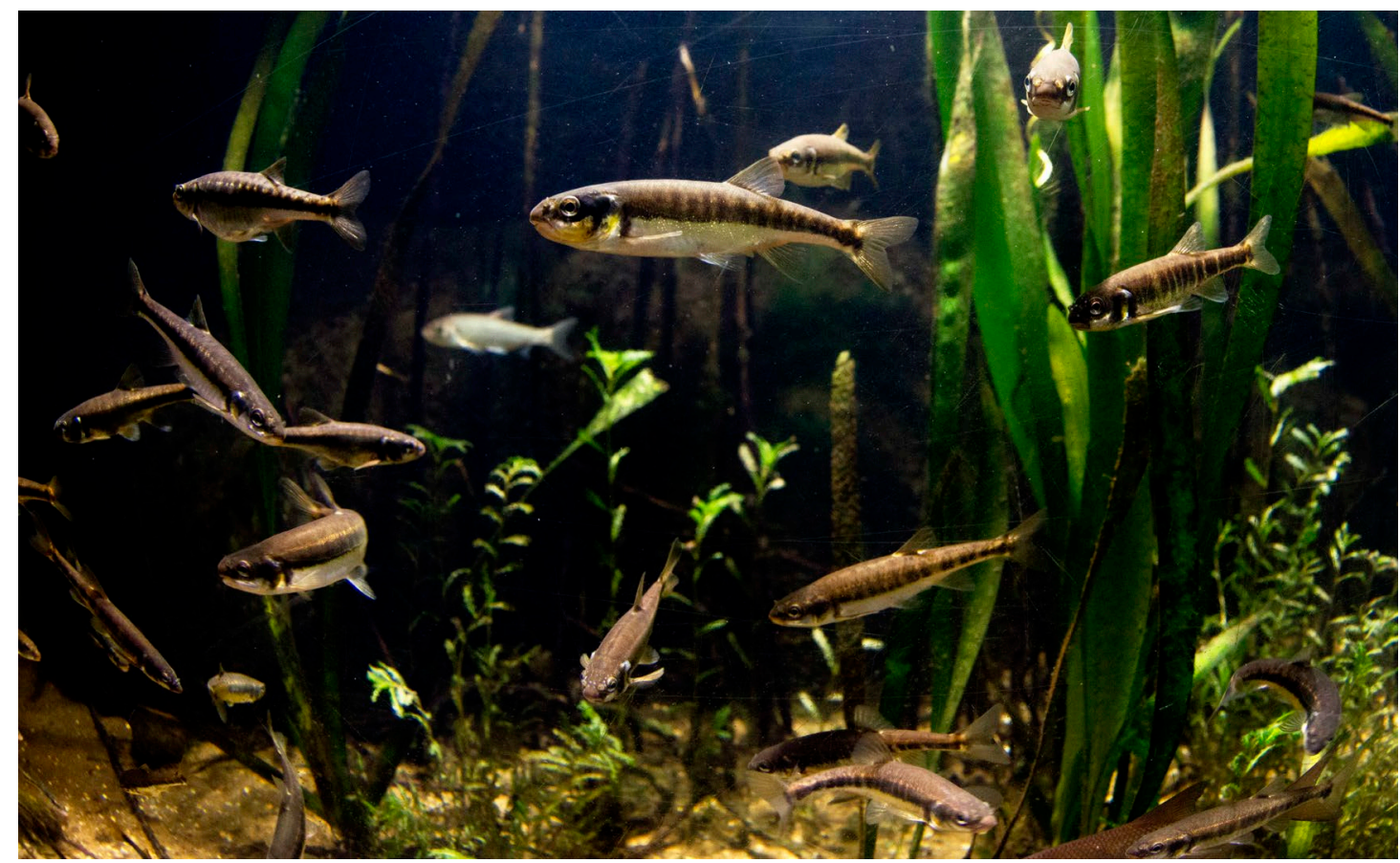

Figure 3. A school of European minnows (Phoxinus phoxinus). Photo: Ruben A. Pettersen

The European minnow spawns from April to August, with females producing multiple clutches throughout the season. Life history parameters such as egg size, clutch size, age and length at maturation varies with latitude (Mills, 1988). The minnow prefers shallower parts of the littoral zone and rivers, where they often congregate in schools (Figure 3). As they grow, they use more of the river 
or littoral zone and sustain schooling behaviour for the rest of their lives. However, they do not necessarily coincide with siblings (Bernhardt et al., 2012). The life history strategies in minnows give Gyrodactylus spp. a good opportunity to transmit during most of their life cycle, and generations of minnows overlap in their habitat use.

The Atlantic salmon are anadromous, meaning that they migrate from the sea to spawn in freshwater. After one to four years in the sea, they return in autumn to their freshwater nursery areas to spawn. The juvenile period of Atlantic salmon in rivers varies with food availability and temperature. In Northern latitudes it may take up to four years before they migrate to sea, contrasting with more southern areas where they return after a year (Stradmeyer et al., 2007). After spawning, many Atlantic salmon die, but some survive and can spawn for repeatedly. Others return to sea immediately after spawning or stay in rivers through the winter season. As Gyrodactylus do not tolerate seawater, salmon can only be infected in the freshwater stage of their life history (Soleng \& Bakke, 1997). The Atlantic salmon is regarded as important for the human community and has its own conservation organization ${ }^{4}$, a post on the Norwegian state budget, and is considered a flagship species (Mills, 2007) in IUCN 5 . The Norwegian management authorities have estimated a socio-economic loss of approximately 3-4 billion Norwegian kroner (NOK) as a direct consequence of the G. salaris epidemic in Norway. As a result, strict regulations for fish dispersal have been issued by the Norwegian government.

\section{The colonization history of the parasite}

Dispersal occurs when an individual permanently leaves its natal home range and emigrates to a new patch or population - which is important for demographic and evolutionary dynamics of populations (Stenseth \& Lidicker, 1992). Under changing environmental conditions, dispersal may act as a key life history trait that governs the adaptive response of individuals (Ronce, 2007; Rousset \& Gandon, 2002). Theoretically, there will be a trade-off between local adaptation and the degree of dispersal plasticity (Arendt, 2015; Barber et al., 2016). Plasticity in dispersal decision could have an important role in the establishment of populations, in local adaptation, and ultimately in speciation (review by Arendt 2015). This will, over time, be revealed by the genetic structure of populations of parasite and host (Poulin, 2007).

What factors determine distribution of Gyrodactylus in space and time following their colonization into Norway? First, host individuals must be infected with Gyrodactylus, and they must survive the dispersal into a new area. However, in a colonization wave not all hosts will arrive to the same area, behaving as a diminished demographic colonization front (Arendt, 2015; Boulinier et al., 2016). Population genetic structure, dispersal and gene flow among both host and Gyrodactylus populations

${ }^{4}$ NASCO, North Atlantic Salmon Conservation Organization

5 International Union for Conservation of Nature and Natural Resources (IUCN) 
may facilitate transmission of parasites and may also affect evolution of parasite resistance in hosts (Boulinier et al., 2016; Huyse et al., 2005). In a metapopulation framework (Hanski, 1999), Gyrodactylus populations may originate or go extinct depending on the fate of their host populations, where connection between segments is important for the overall survival of the metapopulation (Hanski, 1999). The evolutionary interaction of host and Gyrodactylus may be different in a river transect of consecutive populations than in a lake system. The density and behaviour of both hosts and Gyrodactylus may be important with regard to horizontal transmission as well as population dynamics of Gyrodactylus among its hosts (Bernhardt et al., 2012; Huyse \& Volckaert, 2005). Host populations may need to be of a certain size in order to uphold a viable population of Gyrodactylus due to temporal dynamics in the immuno-response of the host and associated stochastic demographic events in the Gyrodactylus population (Alvarez-Pellitero, 2008). Further, demographic bottlenecks may result in reduced genetic diversity in the host species and may affect the viability of Gyrodactylus populations. Genetic diversity, as seen in neutral microsatellites (e.g. heterozygosity), may provide a proxy for general genomic diversity, potentially reflecting diversity also in genomic regions that are targeted by natural selection (e.g. parasite resistance and adaptability in new environments) (Blanchet et al., 2010). Neutral microsatellite heterozygosity is hypothesized to be associated with fitness in several studies, with regard to parasite infection and resistance of hosts (Blanchet et al., 2009; Mazè-Guilmo et al., 2016). Here, the assumption is that a genetically diverse host has a more robust immune system to handle parasite infections than more homozygotic hosts (Collin et al., 2013; Voegeli et al., 2012). Other important factors for population growth and survival of Gyrodactylus are abiotic factors such as water chemistry and temperature (Jansen \& Bakke, 1991; Pettersen et al., 2006a, b; Poleo et al., 2004). In situations of human influenced dispersal of parasites and host our knowledge is even less. The results from a meta-analysis of parasite-host associations have challenged the existing paradigm that there is a close link between parasite and host, which results in the genetic structure of the parasite being largely contingent upon the host dispersal behaviour. Here, a low degree of genetic structure association with host dispersal behaviour was observed, indicating that other factors are important for the population genetic structure and dispersal of parasites (Mazè-Guilmo et al., 2016).

\section{The colonization history of the host}

One of the major factors affecting the current distribution patterns of natural organisms throughout the Holarctic is the Weichselian glaciation. This has had a huge influence on both glacial refugia and subsequent colonization patterns through dispersal (Hewitt, 1996). In Scandinavia, the region's short biogeographical history since the last glaciation, its geographical location, and the topography of drainage basins, have largely determined the composition of its native freshwater fishes (Holmen, 2013; Huitfeldt-Kaas, 1918; Koskinen et al., 2000; Refseth et al., 1998; Østbye et al., 2005). Furthermore, the rising of the landmass following the glaciation strongly affected how different groups of fish species colonized Norway from various geographic areas and water systems (Huitfeldt-Kaas, 
1918). Here, the anadromous Atlantic salmon colonized Norway along its entire coastline likely from a southern and northeastern glacial refugium (Verspoor et al., 2012). The European grayling and the minnow colonized Norway from a southern and a northern glacial refugium (Holmen, 2013; Koskinen et al., 2002a). The first group of European grayling and minnow to colonize Norway likely came from a refugium near the Caspian basin, while the second group could have come from a glacial refugium in the central area of Europe (Holmen, 2013; Koskinen et al., 2002c). These latter clades (grayling and minnow) were able to colonize the largest river system in Norway (the River Glomma) and the largest lake in Norway (Lake Mjøsa) from the southeast. In addition, humans in Norway have recently translocated the minnow to several water systems (Hesthagen \& Sandlund, 2004; Museth et al., 2007).

\section{Translocated fish hosts and the dispersal of Gyrodactylus spp. communities}

The European minnow is considered an invasive species in Norway, where some newly established minnow populations have originated due to large-distance human mediated dispersal (Holmen, 2013; Museth et al., 2007). Translocated species may become invasive and can impose major negative ecological effects (Rahel \& Olden, 2008). Invasive species comprise an important part of worldwide biodiversity change having enormous economic costs to society (Gherardi et al., 2011; Perrings et al., 2005; Pimentel et al., 2005). Introduction of new species may also function as a vector for the establishment of new parasites and diseases that may infect naive native hosts in the receiving area (Peeler et al., 2011). Such transmission may lead to diseases, where parasites impact native species, or populations, due to a lack of co-evolution with the introduced pathogens, potentially leading to large population dynamic effects (Parker et al., 1999). Alternatively, this may also release introduced species from their co-evolved pathogens in novel environments. This "enemy release hypothesis (ERH)" which predicts that translocated host populations (i.e. populations moved by humans) may lose their parasite species diversity compared to natural populations (Elton 1958). If only a few individuals are the founders of a new population, they may be able to grow and spread rapidly, particularly without limitations of parasites or diseases. Comparing native and introduced plant species, Mitchell \& Power (2003) found that introduced plants harboured less fungi and virus than plants in their native habitat (Mitchell \& Power, 2003). Further, Torchin et al., (2003) compared 26 host taxa and showed that introduced species had half the number of parasites as native species. A more recent review by Heger \& Jeschke (2014) compared 176 studies when addressing the ERH and found almost as much support (36\%) as questioning of the evidence (43\%). Thus, some support exists for the ERH as a general phenomenon across distant taxa.

\section{The aim of the thesis}

The main objective of this thesis has been to obtain a better understanding of the evolutionary history of dispersal patterns of the monogonean parasite Gyrodactylusthymalli with regard to fish hosts and time scales, in natural and human influenced freshwater systems. I accomplished this by first 
investigating the population genetic structure of $G$. thymalli on the European grayling in the large River Glomma (Figure 4), representing a framework of linear dispersal gradients (Paper I). In contrast, I also studied the genetic structure of host and parasite in a large lake, Lake Mjøsa, representing an open system with many spawning populations of grayling where dispersal could occur among all populations (Paper II). The colonization patterns of these taxa in the River Glomma and Lake Mjøsa are due to natural dispersal following the retreat of the last Pleistocene ice sheet. However, during the last century, humans have influenced dispersal of both fish species and their parasite taxa. In paper III, I focused on both natural and translocated minnow populations and their Gyrodactylus species. By analysing the genetic structure of minnow hosts, I investigate a contrast between natural stepping-stone dispersal and long-distance dispersal events due to human interaction. Finally, I studied the physiological mechanisms of pathogenicity of G. salaris on Atlantic salmon (Paper IV) representing a parasite with huge population impacts on Atlantic salmon, and a further example of human influence on dispersal. 


\section{SUMMARY OF RESULTS}

Currently, little knowledge exists concerning the structure of genetic variation among populations of G. thymalli. In Paper I, I characterized genetic diversity, differentiation and structure of G. thymalli living on grayling at 20 localities in the large River Glomma, Norway. Here, I compared two separate mitochondrial DNA genes to study postglacial colonization of individuals from potentially different glacial refugia. I expected that populations were differentiated due to isolation by distance (IBD) mechanisms (Wright, 1943). Two glacial mtDNA lineages of grayling have earlier been identified in the River Glomma (Koskinen et al., 2002b), thus I also expected that G. thymalli could reveal mtDNA footprints of these two glacial refugia, due to the long history of co-occurrence of parasite and host.

In G. thymalli within the Glomma river system, I observed three main clusters of haplotypes dominating the three distinct geographic parts of the river system; one cluster dominated in the western main stem of the river (River Gudbrandsdalslågen with the large Lake Mjøsa), one in the eastern (the upper River Glomma) and one in the lower part (the lower River Glomma after the confluence of River Gudbrandsdalslågen and upper River Glomma)(Figure 5). There was a significant IBD signature, with a positive relationship between hydrographic distance and population genetic distance. The genetic variation observed in the different sub-populations indicates long time scale isolation, evaluated based on the finding that more than $80 \%$ of the populations had private haplotypes. In order to put my COI haplotypes from Paper I into a larger context, I made a Maximum Likelihood evolutionary tree with a new algorithm in MEGA 7 (Kumar et al., 2016). The tree separates the River Glomma clade from other European samples (91\% bootstrap) and southern populations (Sarpsborg, Nittedal, Kongsvinger) grouped out inside the River Glomma clade (89\%) (Figure 5). I have also reanalysed the data from Paper I using the new Maximum Likelihood tree and calculated divergence times between River Trysilelva and River Glomma clades. The new divergence time was estimated to be between 4320-5680 years when G. thymalli colonized River Glomma (reported in Paper I as a confidence interval of 680-5000 years). Lake Mjøsa was one locality in the Glomma river system (the River Gudbrandsdalslågen part) that showed large genetic variation. This may indicate that grayling colonized the area around Lake Mjøsa from two glacial refugia, respectively from a northern refugium and southeastern refugium (Paper I). I therefore wanted to investigate further the reason for this large variation (Paper II). To study this, I looked at the population genetic structure of the host using high resolution genetic markers. Microsatellites can reveal recent population divergence and gene flow among geographical samples; revealing insight into how parasites and hosts interact with regard to shaping population genetic structures in an open system with putative gene flow following their postglacial colonization. 


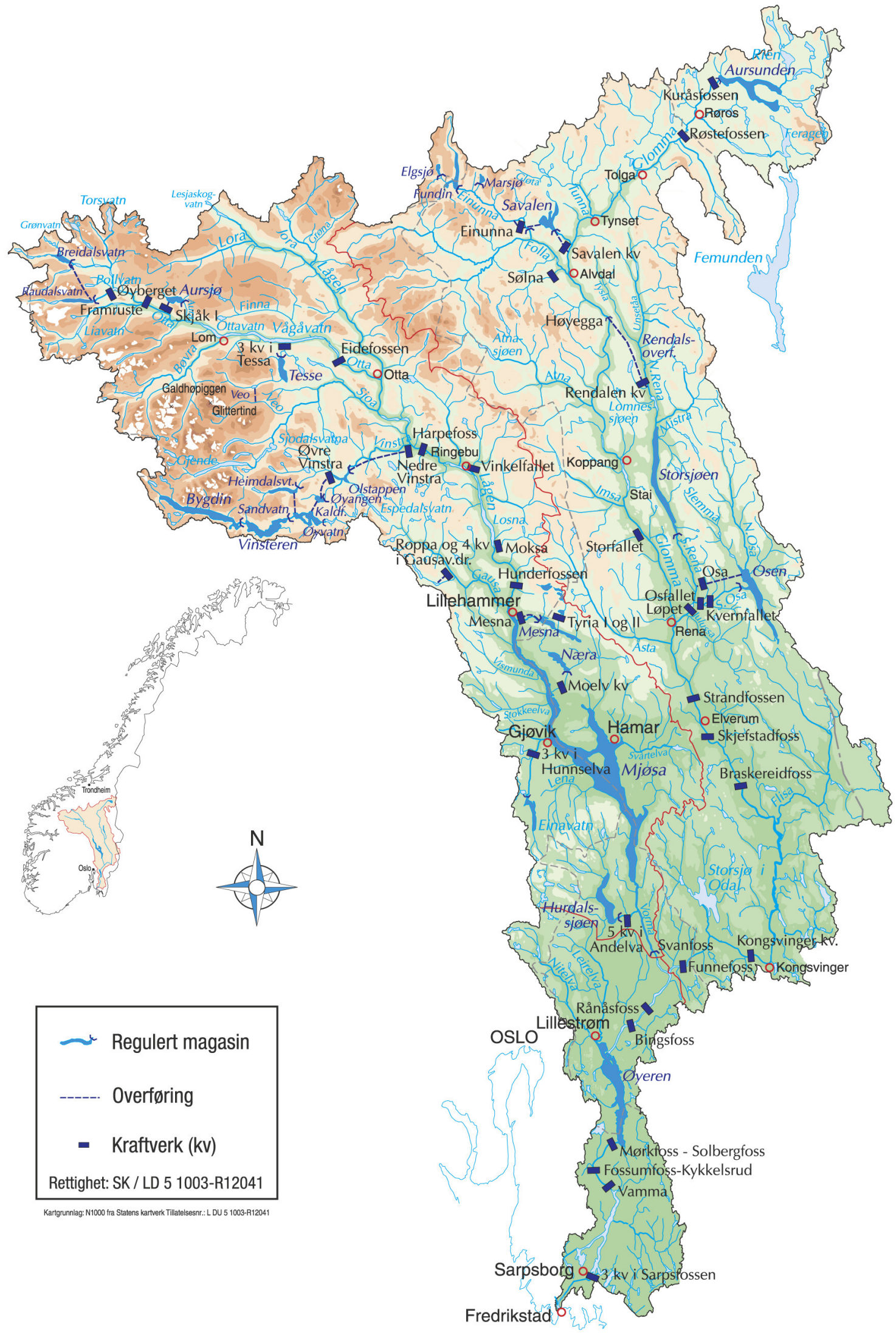

Figure 4. This map shows the Glomma river system, with Lake Mjøsa. Gyrodactylus thymalli and European grayling (Thymallus thymallus) were collected from locations along this riversystem. The map is provided by the Norwegian Mapping Authority. 


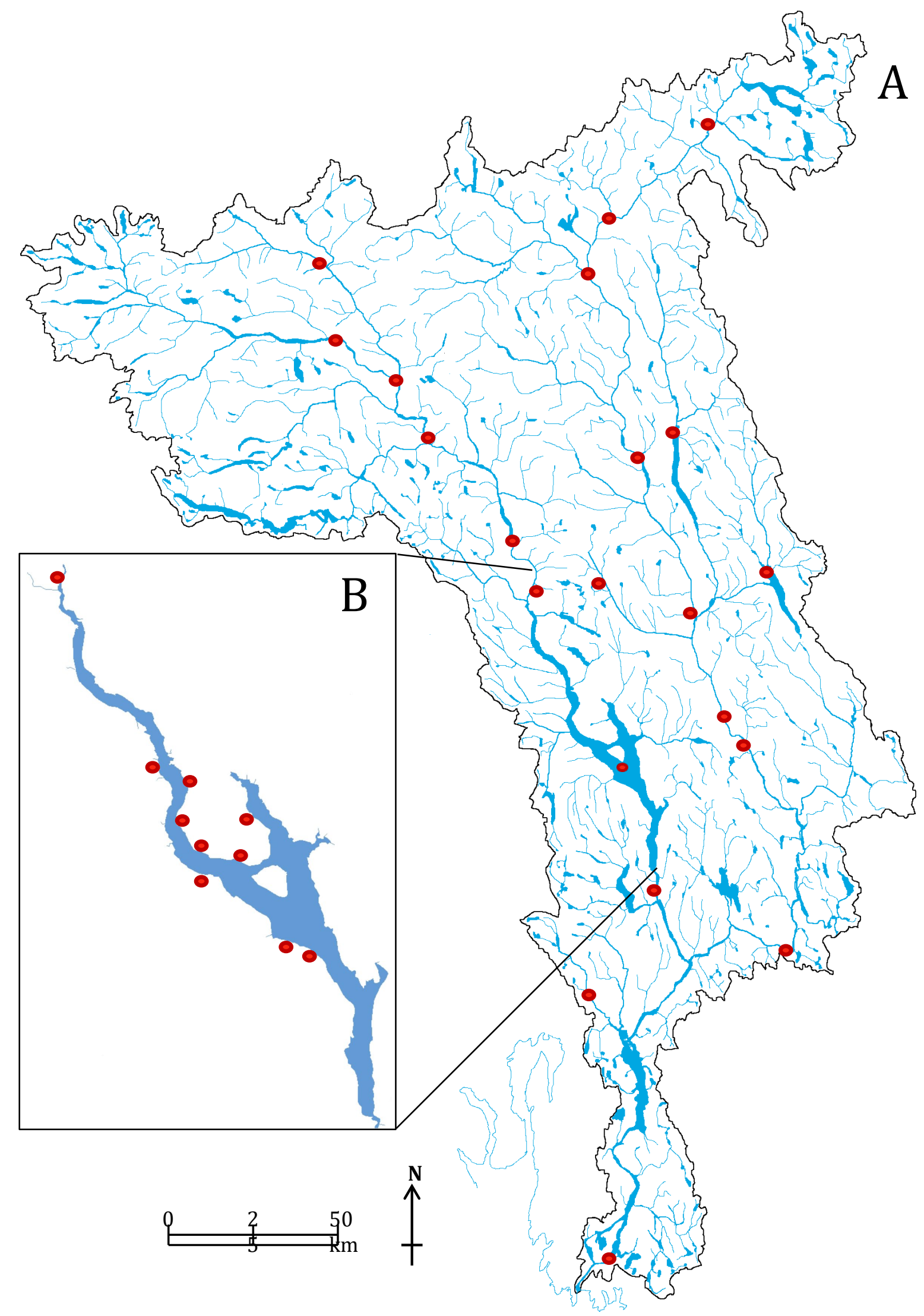

Figure 5. This map shows only the watercourses from figure 4 of the Glomma river system (A) from Paper I, and the inserted panel shows Lake Mjøsa (B) from Paper II. The red dots mark the sampling locations along this river system where Gyrodactylus thymalli and European grayling (Thymallus thymallus) were collected. 
In Paper II, I compared G. thymalli - grayling genetic structure in Lake Mjøsa, using the same river system as in Paper I, where different spawning populations of grayling exist. It is unclear how the genetic structure of G. thymalli may depend upon the spawning fidelity of its grayling host in a large lake where grayling spawning occurs in different tributaries. I predicted that if there were strong homing behaviour in grayling and if transmission of $G$. thymalli was mainly occurring during spawning, then the genetic structure of G. thymalli and grayling should display a coherent pattern (Mazè-Guilmo et al., 2016). To test this, I analysed the correlation between genetic distance and geographic distance and investigated to which degree the genetic structure of $G$. thymalli and its grayling host were correlated. In Paper I, I found that the genetic structure of G. thymalli was correlated with the geographical distances of their grayling hosts in a large river system. Paper II showed two genetic clusters of grayling, one in a large spawning tributary and all remaining tributaries clustered in another. Both taxa revealed significant $\mathrm{F}_{\mathrm{ST}}$ or $\varphi_{\mathrm{ST}}$ values among tributaries. The highest genetic variance was found within spawning tributaries, supporting low genetic differentiation among most geographical comparisons. None of the isolation-by-distance patterns were significant, nor was the correlation between genetic distances for the two taxa. 


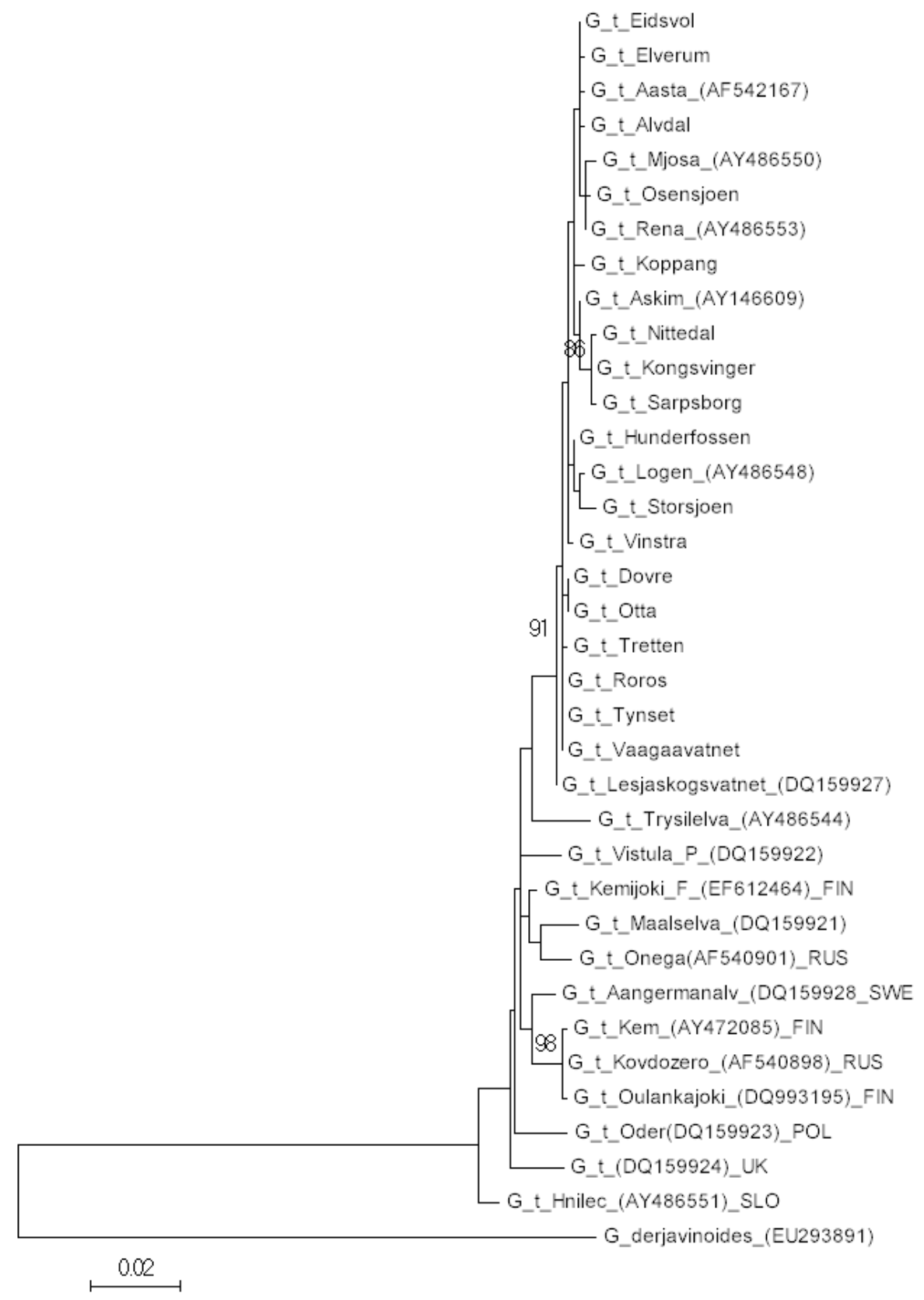

Figure 6. A Maximum Composite Likelihood tree (Kimura, 1980) of G. thymalli with the highest log likelihood (- 2371) shown. The tree is based on mitochondrial cytochrome oxidase I, 36 haplotypes on a 777 bp alignment from Paper I and gene bank. Evolutionary distances used was Kimura 2-parameter model (Kimura 1980) in MEGA7 (Kumar et al., 2016). Values are calculated from 10000 replicates (Felsenstein 1985) and bootstrap values of less than $80 \%$ are not shown. The scale bar indicates 0.02 substitutions. The tree was rooted with $G$. derjavinoides Malmberg, Collins, Cunningham \& Jalali, (2007). Abbreviations: G_t; G. thymalli, FIN; Finland, POL; Poland, RUS; Russia, SLO; Slovakia, SWE; Sweden, UK; United Kingdom. All other haplotypes are from Norway. Genbank number is given inside the parenthesis.

In Papers III and IV, I have addressed human influence and its putative impact upon distribution of parasites, as well as human influence on a documented case of a detrimental pathogenic invasive 
parasite species. Humans may affect the distribution of parasites through translocation of hosts and through introductions of invasive species or genetic variants of parasites. However, little effort has been invested in studying such systems with regard to presence of Gyrodactylus spp. comparing natural and human influenced systems. The minnow has a natural distribution in Norway, but it has also been introduced to areas outside its natural distribution area to a high degree (Figure 7). In Paper III, I tested the ERH by comparing Gyrodactylus species diversity in natural and translocated populations of minnows across Norway. I also used microsatellites to test for demographic expansion and bottleneck events in translocated and natural minnow populations. Further, I tested if there was an association between heterozygosity and parasite load in populations. I expected that translocated minnow populations were first bottlenecked then experienced a subsequent demographic increase. According to the ERH, I expected that translocated minnow populations had a lower parasite load and diversity. Finally, I expected that parasite load was negatively correlated with heterozygosity, used as a proxy for fitness, implying that individuals with higher genetic diversity have a lower parasite load. The results showed that native and introduced minnow populations had similar species compositions of Gyrodactylus, which does not support the ERH. The two minnow groups did not differ in the likelihood of being infected with Gyrodactylus. Considering only infected minnow populations, it was evident that native populations had a significantly higher mean number of Gyrodactylus individuals (species pooled) per host than introduced populations. The results showed that homozygotic minnow individuals had a higher Gyrodactylus infection load than more heterozygotic hosts. There was no evidence of demographic bottleneck in the minnow populations, implying that translocated populations retained a high degree of genetic variation, which could partly explain similar species composition of Gyrodactylus in the two compared minnow groups. 


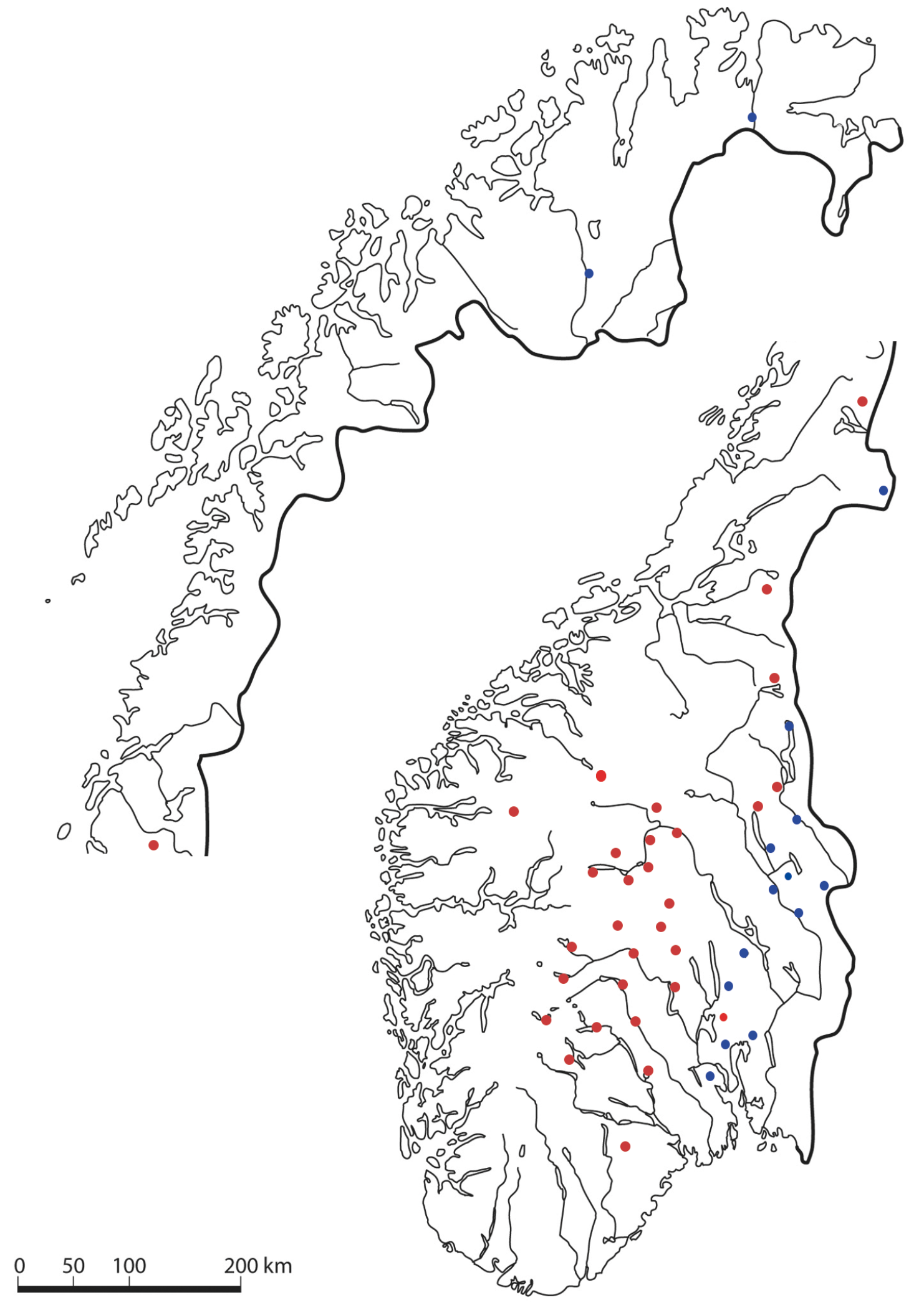

Figure 7. This map shows sampling locations of minnow (Phoxinus phoxinus) populations in Norway (Paper III). Red dots mark introduced minnow populations and the blue dots mark native minnow populations. 
Parasites that are moved into new locations, meeting naïve hosts, can lead to unexpected consequences. The introduced parasite $G$. salaris has had huge socio-economic costs by being a pathogenic agent on Norwegian Atlantic salmon (Johnsen \& Jensen 1986, 1991). However, the pathogenesis has not been well described and is still not well understood (Bakke et al., 2007). Thus, in Paper IV, I conducted a controlled laboratory experiment studying the specific temporal pathogenesis of Atlantic salmon due to presence of G. salaris. The hosts originated from River Lærdalselva and G. salaris from River Lierelva. Here, I measured a set of blood parameters, related to osmoregulation function in the host, as the infection developed. I expected that a high parasite load with numerous penetration events of the skin would result in ion leakage leading subsequently to osmoregulatory failure and ultimately death. At the end of the experiment (61 days) the mean number of parasites per individual had reached almost 3000. At the same time, infected juveniles showed a distinct loss of blood plasma ions, decreased hematocrit and increased plasma glucose levels. Concomitantly, fish mortality increased. In conclusion, a heavy G. salaris infection causes osmoregulatory failure and stress, leading to increased mortality in Atlantic salmon juveniles. 


\section{DISCUSSION}

\section{Natural dispersal of Gyrodactylus spp. on grayling and minnow hosts across space and time}

Following the deglaciation of the Weichselian ice sheet the waterways were now open for colonization by grayling into Norway from two main glacial refugial areas - one from the northeast and one from the southeast (Koskinen et al., 2000). Along with the colonization of grayling, the ectoparasite $G$. thymalli colonized the same areas, being contingent upon the dispersal of its host (Hansen et al., 2007a). In river Glomma, I observed three lineages of mtDNA COI gene that corresponded well with Hansen et al., (2007a) (Figure 4). However, I found a larger diversity in haplotypes than previously observed by Hansen et al., (2007a) related to the River Glomma. This is likely related to sample size as I have studied 309 fish (revealing 35 haplotypes) while Hansen et al., (2007a) studied 10 fish (8 haplotypes). All eight haplotypes in Hansen et al., (2007a) were also detected in my study (Figure 4). Thus, large scale versus small scale sampling approaches may be useful for different phylogeographic investigations, where a denser sampling scheme should be used for population genetic studies.

The Glomma river system represents a linear gradient of consecutive dispersal events where I expected the genetic structure of $G$. thymalli along the river to show higher genetic diversity in the lower sections than in the upper reaches of the river, conforming to an IBD pattern (Paper I). I also looked at Lake Mjøsa, which represents an open water system with several spawning populations of grayling, where dispersal of G. thymalli could occur across all populations (Paper II). Here, I also expected an IBD pattern due to homing behaviour of the grayling, as well as a preference of littoral zone occupancy related to the shoreline dispersal of grayling. Based on Koskinen et al., (2000), it is likely that grayling colonized the area around Lake Mjøsa from two glacial refugia, respectively from the north and from the southeast. A larger population of G. thymalli in Lake Mjøsa may hold a larger gene pool of mtDNA variants than smaller populations in the River Glomma (Paper I and II). This may result from the contact zone of its host, among grayling in the Lake Mjøsa area, as well as from putatively larger diversity originating in larger populations in Lake Mjøsa than in River Glomma. At the same time, one should expect that genetic diversity was higher in the lower reaches of River Glomma, sequentially being reduced along with the colonization wave upwards (Paper I and II). I have reanalyzed the data from Paper I with a new phylogenetic method, the Maximum Likelihood algorithm. I found that the three southern populations (Sarpsborg, Nittelva, Kongsvinger) grouped out of the tree in a separate clade (Figure 4). This means that the G. thymalli clade in the River Glomma has most probably colonized from the south. In the two contrasting systems, I found a significant IBD pattern in the linear gradient along the River Glomma, while no significant IBD patterns were evident in Lake Mjøsa. The pattern in River Glomma is concordant with the existing theory (Wright 1943) that genetic distances increase with the geographical distances among populations (IBD). Thus, it is logical to assume that grayling will also show an associated IBD pattern as G. thymalli is contingent upon its 
host dispersal. This remains to be tested, however, this makes sense given that the studied distances among grayling populations range from a few kilometres up to $600 \mathrm{~km}$. However, the lack of a significant IBD pattern of grayling in Lake Mjøsa implies that homing is less precise than expected and that grayling are not necessarily constrained by dispersal along the shoreline habitat as expected. The genetic pattern evaluated with regard to potential transmission of G. thymalli in the linear gradient of River Glomma versus the open water system in Lake Mjøsa shows that the likelihood of encounter rate and gene flow of $G$. thymalli among different hosts from geographically separated populations is likely higher in Lake Mjøsa than in River Glomma. Or, mtDNA may not be suitable for testing IBD in general (see Teske et al., 2018).

When combining genetic data on G. thymalli from River Glomma and Lake Mjøsa, a MANOVA analyses showed three significantly different groups of populations (Paper I, II). Here, one group was found in the upper parts of the Glomma River, one in River Lågen and one in the lower part of the Glomma river system. This partitioning was supported by the median-joining network phylogenetic analysis (Paper I). In view of the re-analysed data showing new divergence time estimates of 43205680 years between $G$. thymalli populations in River Trysilelva and River Glomma, divergence is set within a period after deglaciation. Further, the three MANOVA groups could have originated within the River Glomma or, alternatively, represent different colonization waves. In Koskinen et al. (2000) two main mtDNA clades of grayling were revealed, one in northeast and one in southwest, which met in a contact zone in the Lake Mjøsa area. Thus, the three lineages G. thymalli in Lake Mjøsa likely result from the contact zone of grayling (Gum et al., 2006). In comparison, in a phylogeographic study of G. arcuatus Bychowsky, 1933 on the three-spined stickleback (Gasterosteus aculeatus L.) two main allopatric clades were found, one in the centre of Europe and one in the North, which spread across the Barents Sea and White Sea (Lumme et al., 2016). Thus, a general and similar geographical pattern can be found in parasite genetic structure in different species on different hosts (Kudlai et al., 2017).

The dynamics between the host and the parasite is dependent on adaptation to the environment, and reflects adaptation with regard to their interactive arms race (Benton, 2009; Engering et al., 2013). In contrast to a "stepping-stone colonization scenario" in River Glomma, the open water system in Lake Mjøsa reveals a system where the hosts can move freely between spawning habitats. Evolution of population genetic structure of hosts and their parasites are little studied (see review Mazè-Guilmo et al., 2016). In such, the host-parasite system of G. thymalli and grayling are a good model system to address this issue, particularly with the short evolutionary time frame following deglaciation. Thus, I studied their colonization dynamics in Lake Mjøsa, spanning thousands of years, by comparing the genetic structure of both taxa (Paper II; Auld \& Rubio de Casas, 2013). The spawning tributaries of grayling that I studied in Lake Mjøsa are in general seasonal (Paper II; Kristiansen \& Døving, 1996), 
and may in some years actually dry out (personal observation). A consequence of this unpredictability may have led to the evolution of a bet-hedging strategy in spawning grayling as a response to stochastic demographic dynamics in tributaries (see theory in Rousset \& Ronce, 2004). Initially, I expected a strong homing behaviour in grayling as a previous study in these streams have documented strong philopatry between two successive spawning seasons (Kristiansen \& Døving 1996). In Paper II, two genetic clusters were evident in the grayling in Lake Mjøsa, being the large spawning tributary in the north of the lake, while the remaining tributaries belonged to the second cluster. Furthermore, as no significant IBD pattern was identified in grayling or in $G$. thymalli, this suggests lack of geographic genetic structuring in both organisms. The AMOVA results for G. thymalli suggested differentiation among the eastern and western side of the lake rather than between the two genetic groups of grayling. In such, could this pattern reflect a meta-population system (Hanski, 1999) in Lake Mjøsa? In comparison, Junge et al., (2011) detected a significant IBD pattern among a set of spawning grayling locations in Lake Lesjaskogsvatn, Norway. The investigated tributaries in Lake Mjøsa are approximately the same size as the tributaries in Lake Lesjaskogsvatnet (Paper IIKristiansen \& Døving 1996; Koskinen et al., 2002b; Junge et al., 2011). However, the geographic distance among spawning tributaries in Lake Mjøsa is much larger than in Lake Lesjaskogsvatnet. Thus, I expected stronger IBD patterns among tributaries in Lake Mjøsa than in Lake Lesjaskogsvatn, which was not the case (Paper II). I also expect that the longer evolutionary time of grayling in Lake Mjøsa (likely deglaciated ca. 8000 years ago, compared to Lake Lesjaskogsvatn that was stocked with grayling roughly 80-120 years ago, Koskinen et al., (2002a,b) should reveal a more pronounced genetic differentiation. In such, the significant IBD pattern in Lake Lesjaskogsvatnet could be an effect of the early stages of population divergence, where, after some time, homing may evolve (Koskinen et al. 2002a; Junge et al. 2011). Theoretically, I expect that dispersal rate could vary over time among spawning tributaries, starting high where colonists were dispersers (small founder size), but declining with time if philopatry becomes adaptive (Olivieri et al., 1995; Roff, 1994). However, this assumption may be wrong. It could be that the optimal reproductive strategy in grayling is bet-hedging among tributaries (review by Hopper, 1999). In spite of a long evolutionary time, the genetic structure may not actually evolve in grayling or G. thymalli in Lake Mjøsa. Such an evolutionary strategy may reflect conditions during the early colonization phase in barren and unpredictable areas after the ice age where a philopatric strategy may not have been the most optimal.

The dispersal of parasites is dependent on their host (review by Bozick \& Real, 2015), but how strong is host dispersal as a driver of the genetic structure and variation between host and parasite? One of the paradigms is that the genetic structure of the parasite is expected to have the same or a corresponding genetic structure to their hosts, because host dispersal determines parasite dispersion patterns (e.g. Jarne \& Theron, 2001; review by Mazè-Guilmo et al. 2016). This assumption is based on studies comparing genetic structure of parasite and host population, by using among-population 
genetic differentiation such as $\mathrm{F}_{\mathrm{st}}$ and $\Phi_{\mathrm{st}}($ Holsinger \& Weir, 2009; Meirmans \& Hedrick, 2011; Paper II). However, there is a possibility to calculate the correlation coefficient of genetic differentiation between host and parasite (McCoy et al., 2005, 2012; Paper II). Findings suggest that host and parasite dispersal rates may be closely linked to each other, indicating spatial correspondence between host and parasite population genetic structures (Nieberding et al., 2008). However, low genetic differences between host and parasite populations may result from other factors such as large effective population size and massive migration between populations (Criscione, 2008; Holsinger \& Weir, 2009). Mazé-Guilomo et al., (2016) conducted a meta-analysis of multiple gene structures in taxonomic groups of hosts and parasites and found that the genetic differentiation was lower in parasites than in hosts. These findings correspond well with my results from Lake Mjøsa, where genetic variation among $G$. thymalli tributaries $\left(11 \%, \Phi_{\mathrm{st}}\right)$ was much lower than among grayling tributaries (64\%, $\mathrm{F}_{\mathrm{st}}$ ) (Paper II). However, I did not expect this lower genetic variation in G. thymalli, because G. tymalli has a shorter generation time than grayling (Bakke et al. 2007). A shorter generation time is predicted to drive evolutionary rates faster (Price, 1977), and thus provide genetic differentiation faster in space and time (Huyse et al., 2005). However, in a meta-analysis of many genetic markers in diverse taxonomic groups, Mazé-Guilomo et al. (2016) found that the genetic structure was weaker in parasites with asexual reproduction compared to parasites with sexual reproduction. They explain this with sexual reproduction maintaining genetic polymorphism, while asexual reproduction reduces it (Fox et al., 1996; Liu et al., 1996; Huyse et al., 2005). In a phylogeographic study of mtDNA in G. gondae Huyse, Malmberg \& Volckert 2005 and its host, the sand goby (Pomatoschistus minutus Pallas, 1770), in an "open water system" along the Atlantic coasts of Europe, Huyse et al., (2017) found a postglacial expansion in both species. Huyse et al., (2017) found that in the pairwise comparisons $\left(\Phi_{\mathrm{st}}\right)$ among populations within parasites and hosts, it was evident that the parasite had the lowest genetic diversity. Rahn et al. (2016) studied genetic differentiation (microsatellites) in threespine stickleback and eye-fluke Diplostomum pseudospathaceum Niewiadomska, 1984 in a set of 19 freshwater lakes and found that there was a strong genetic differentiation of the host versus the parasite. Again, these patterns fit with my results according to the genetic differentiation of G. thymalli on grayling in Lake Mjøsa (Paper II). Since such a pattern is revealed among different parasites on various hosts, and when using different genetic markers, this may point to a general phenomenon in co-evolution of hosts and parasites. However, it is difficult to compare host and parasite taxa with different reproductive systems (asexual versus sexual), different generation times (age at maturity) and different genetic markers with different mutation rates (reflecting different evolutionary time aspects) (Paper II). Despite this limited knowledge, it is still important to ask questions of how fast evolution or genetic drift (or both) may act on a short time scale such as in postglacial northern lakes with regard to host and parasite systems. 
Parasite dispersal is limited by abiotic environmental factors, but it also depends on the availability of hosts and the host's requirements and environmental needs (reviewed in Bozick \& Real, 2015). All grayling populations I examined had G. thymalli infections, with the exception of one, where grayling was stocked only 100 years ago (Paper I and II). In contrast to this high prevalence of infection, there were many minnow populations where I did not detect Gyrodactylus species, which could be related to habitat characteristics (Paper III). For example, the richness or structure of Gyrodactylus communities in fish populations of the same species often correlates with selected physicochemical characteristics of the water bodies they inhabit (Bakke et al., 2007). Some characteristics, such as $\mathrm{pH}$, chemical characteristics, depth and latitude, determine if parasites can exist in given lakes (Kennedy, 1978; Marcogliese \& Cone, 1996; Pettersen et al., 2006b; Poleo et al., 2004; Smallbone et al., 2016). A study of threespine stickleback from lake and stream habitats, separated 100 years ago, found that sticklebacks from streams were more resistant to Gyrodactylus spp. and had a different major histocompatibility complex (MHC) gene expression pattern than sticklebacks from lake habitats (Brunner et al., 2017). This may indicate that the environment may have an impact affecting the evolution of host-parasite systems. At the same time, stickleback specialists such as G. gasterostei and G. arcuatus have large variation in virulence (Robertson et al., 2017). Differences in prevalence between grayling and minnow host with regard to parasites, may be due to several reasons (Paper I, II, and III). First, these host-parasite systems have evolved for a very long time each in their own arms race. Secondly, both host-parasite systems likely respond to various biotic and abiotic selection pressures in different or similar ways. Also, these species have different habitat preferences and life histories. Thus, a comparison is difficult to address.

\section{Translocated fish hosts, minnow and salmon, and the dispersal of Gyrodactylus spp. communities}

Understanding dispersal of parasites and hosts is essential for management of natural and human influenced parasite and hosts populations (Bozick \& Real, 2015; Nentwing, 2007). Stocking of fish can have many unforeseen consequences and may lead to cascading effects in ecosystems; resulting in some species becoming pathogenic while others receive (un)expected benefits (Engering et al., 2013; Woolhouse et al., 2001). For instance, stocking of small brown trout has also led to the unintended introduction of minnows, which have hitchhiked along distance (Hesthagen \& Sandlund, 2004; Museth et al., 2007). In the case of the minnow translocations, there has been no detection of pathogens, however, intentional or non-intentional translocations of minnows can also have profound ecological consequences (Borgstrom et al., 2010; Museth et al., 2007, 2010). The ERH predicts that translocated populations lose their parasite community, thus receiving fitness benefits compared to natural populations, however, I did not find support for this when comparing natural and stocked minnow populations (Paper III). The reasons behind this lack of confirmation could be that the parasites are host-specific, have a direct life cycle, and thus do not have a free-living phase in their 
life cycle (Nieberding \& Olivieri, 2007). These characteristics are expected when the parasite follows the geographical distribution of its host (Bozick \& Real, 2015). Gyrodactylus species conform particularly well to the conditions necessary for transmission, and are expected to have a more efficient dispersal among populations than other parasites (Huyse et al., 2005). The observation that the mean number of Gyrodactylus was lower in introduced minnows in Paper III suggest that the ERH hypothesis may be biased as it often only considers the presence or absence of species without considering the species-specific parasite load of hosts. There may also be several factors occurring concurrently and it is difficult to detect the mechanism when only examining individual factors. Some studies have found strong effects of multiple biological factors that can have an additive effect on parasite load of translocated host populations (Lau \& Schultheis, 2015). It is reasonable to assume that the more diverse parasite species infection a host has, as well as the parasite load of each species, the higher the challenge to the immune system of the host (Zuk \& Stoehr, 2002). I found that the mean number of Gyrodactylus was lower in the introduced minnow populations than in the natural populations (Paper III). A study of introduction of minnow parasites showed that the number of parasite species increased with time after introduction, likely due to repeated introduction of minnows (Daverdin, 1997). In a new environment, the introduced population can speed up its life history, as seen in vendace (Coregonus albula L.) from River Pasvikelva, northern Norway (Amundsen et al., 2012). Regarding detectability of parasite species, time after initial colonization matters. It will be increasingly likely to detect parasite specialists as they need more time to establish than generalist parasite species (Poulin 1997a, b). Furthermore, sample size of parasites is an important issue with regard to detection of the real parasite community that may affect the precision of the estimates considering prevalence and abundance. In Paper III, I find that the newly established minnow population did not show signals of population expansion or bottleneck ( $\mathrm{k}$ and g-tests). In summary, I observed that the mean number of parasite individuals within parasite species were lower in the introduced populations than in native populations. In such, the review performed by Torchin et al. (2003) support my findings in minnows (Paper III).

Furthermore, one could expect that translocated populations harbour lower genetic diversity than the origin population, depending on the number of individuals that were translocated (Forsman, 2014). As a measure of genetic diversity, heterozygosity could be a proxy for revealing genetic diversity when comparing translocated and native host populations. Therefore, I expected to find more homozygotes in my neutral markers in the introduced minnow populations, but this was not the case (Paper III). A meta-analysis of 18 experimental studies addressing translocation and invasive species revealed that high levels of genotypic and phenotypic diversity in founder groups increased establishment success in new environments (Forsman, 2014). This could support my findings that most minnow populations had high levels of heterozygosity (Paper III), potentially improving their ability to colonize new environments. However, I found that homozygosity was positively correlated 
to the parasite burden in both translocated and native minnow populations (Paper III). A support for my finding can be found in a laboratory study of G. turnbulli Harris 1986 infections on guppy (Poecilia reticulata Peters, 1859). Smallbone et al., (2016) also found that the inbred population (high levels of homozygosity) had significantly higher mean parasite number than fish from the control population (low levels of homozygosity). A later study of MHC genes and Gyrodactylus load found no relationship between parasitic infection and MHC genotypes (Hablutzel et al., 2016). However, MHC genes are targeted toward disease and parasite resistance while neutral genes in common population genetic studies are not known to be associated with such a function.

In Paper IV, I studied the physiological mechanisms of the pathogenicity of G. salaris on Atlantic salmon. I found that all salmon parr from the infected group showed a distinct loss of serum ions. Thus, I concluded that a heavy G. salaris infection causes osmoregulatory failure and stress, leading to mortality in salmon juveniles. The feeding activity of $G$. salaris probably causes the most severe damage, leaving ulcers deep into the epidermis, and sometimes even deeper through the basement membrane and into the dermis (Cone \& Dechtiar, 1984; Cusack \& Cone, 1986; Mo, 1994). In a laboratory study, the thickness of the epidermis and the number of mucus cells in salmon juveniles infected with G. salaris were reduced during the early phase of the infection (Sterud et al., 1998). This reduction can cause increased susceptibility to secondary pathogens and reduced osmoregulatory efficiency, leading to mortality (Sterud et al., 1998). Similar results were noted in Gyrodactylus colemanensis Mizelle \& Kritsky, 1967 infections on various salmonids (Wells \& Cone, 1990). In a field study, the epidermis of salmon juveniles infected for a year or more were found to be thicker compared to the epidermis of juveniles from an uninfected population (Appleby et al., 1997).

I calculated the mortality of Atlantic salmon exposed to G. salaris (Paper IV), and found that most salmon died within 61 days of exposure. It is difficult to compare my results with other studies as most studies do not report mortality during the experimental period, but rather at the end of the experiment (often closing the experiment at 40 days) (Bakke et al., 2002; Soleng \& Bakke, 1997, 2001; Soleng et al., 1999, 2005).

I further combined the results of population growth rate of $G$. salaris with the mortality of salmon (Paper IV). In the last week of the experiment, the number of $G$. salaris multiplied with tripled, at the same time the instantaneous mortality rate increased reciprocally. Specifically, G. salaris infection went from an average of 1208 to 2936 parasites, with the instantaneous mortality rate increasing from 0.05 to 0.20 in the infected group (Paper IV). If I compare my laboratory result with field studies of the infected Norwegian salmon population, very few infected fish had more than 1200 G. salaris (Appleby et al., 1997; Mo, 1992). In the same river, the authors found that only three samples had an abundance of G. salaris above 3000 (when measuring 49 samples over six years). These results may indicate that the limit for a $10 \mathrm{~cm}$ salmon is likely $3000 \mathrm{G}$. salaris before the fish dies. A similar 
number of G. salaris, as observed in my study (Paper IV), was found on rainbow trout showing high mortality in fish farm in Lake Ladoga, Russia (Ieshko et al., 2016). Therefore, the impact of G. salaris likely depends on the salmon host size (Mo 1992). This makes intuitive sense since a smaller fish will have a relatively larger surface to body mass relationship (Evans, 1993). Further, bigger fish have more ions than smaller fish, and can survive for a longer time with an infection.

There was no indication of secondary fungal or bacterial infected fish (Paper IV), but this may not be excluded. Under a stereoscope, there was visible edema and/or Sapreolegnia spp. hyphes on the fish skin. In this case, the infection of $G$. salaris increased quickly, likely outpacing most bacterial diseases, which have a longer incubation time in low temperatures (Toranzo et al., 2005). In a study of Nile tilapia (Oreochromis niloticus L.), here G. niloticus Cone, Arthur et Bondad-Reantaso, 1995 increased host mortality followed after exposure to the bacterial pathogen Streptococcus iniae. Pier, 1976However, a similar experiment with only G. niloticus infection had no influences of host mortality (Xu et al., 2007). This does not correspond to the results of a similar study of G. derjavini Mikailov, 1975 and Flavobacterium psychrophilum (Bernadet \& Grimont, 1989) on rainbow trout, where they found that host mortality was correlated to gyrodactylid infection levels but not to bacterial exposure (Busch et al., 2003). Further, a study of G. salmonis (Yin and Sproston, 1948) on book trout found infection caused $44 \%$ mortality, without finding evidence of a secondary infection by bacteria or Saprolegnia spp. (Cusack \& Cone, 1986). However, parasites and bacteria may interact to increase mortality in some fish species.

\section{Future perspectives}

The potential of fish ectoparasites to survive depends mainly on the genetic variation, which is mostly due to genetic drift, founder effects, bottlenecks and demographic processes. Next generation sequencing techniques have the potential to produce huge amounts of useful data, influencing future studies of population genetics and phylogeography (Holsinger, 2010). With whole genome sequencing it becomes possible to compare levels of diversity in different parts of the genome. This has the potential to yield new insights relating to population history and the genomic prevalence of natural selection (Hellmann et al., 2008; Pool et al., 2010). Rapid technological developments are decreasing DNA sequencing costs providing the possibility to increase sample sizes in the analysis (Drmanac, 2011; Hahn et al., 2014). These new technologies can be useful to handle the questions of Gyrodactylus species relationships with minnows, and detect source populations in translocation scenarios (Paper III). New techniques may be used to separate between different populations of $G$. thymalli (Paper I, II).

Alien species can often have higher tolerances for pathogenic diseases than native ones (Woolhouse et al., 2005). In this way, introduced fish can be a reservoir for pathogenic disease and increase disease 
impacts on native species (Mo, 1994; Winger et al., 2008, 2009). The introduction of such fish parasites is usually accidental, often as a consequence of the human-mediated movement of fish into new environments (Halvorsen \& Daverdin, 1989; Johnsen \& Jensen, 1991). With a moving host (i.e. dispersal or stocking), the parasite fauna will also be moved (Paper III). In future studies of the ERH hypothesis, we should try to identify systems where the source population of host and parasite is known. Sampling should be done at different times after the translocation. Data from this type of studies will give us an opportunity to test the ERH-hypothesis in a more proper way then in Paper III.

Some studies have shown that Atlantic salmon strains have different immune responses to G. salaris infections (Bakke et al., 1990, 2004; Cable et al., 2000). A laboratory test of heritability of survival of $G$. salaris infection among 49 families identified 15 families who had survival rates of $10-25 \%$, which gives a heritability of $0.32 \pm 0.10$ on a liability scale (Salte et al., 2010). In Norwegian rivers, the Atlantic salmon infected G. salaris exhibited fast selection through 15 generations and split into two different branches with different life history strategies (Jensen et al., 2017). In rivers with $G$. salaris, there are always a few Atlantic salmon that survive infection (Mo, 1992), although the number is small. It is possible that Atlantic salmon will be able to survive the selective sweeps in the population. A deterministic mathematical model, found that salmon populations should be able to recover from G. salaris infection, though this might take some time (Denholm et al., 2017). The genome of G. salaris and Atlantic salmon have been mapped (Fromm et al. 2014; Hahn et al. 2014). Multiple cell types from the hosts have been investigated, and were found to have an active function in host resistance (El-Naggar et al., 2016; Leal et al., 2016). However, we need more knowledge on the specific immune response of Atlantic salmon to G. salaris (Paper IV). By studying this mechanism, we may be able to detect errors in DNA within the strains of Atlantic salmon that have low immune response to G. salaris. This knowledge will provide the basis for new tools for drug discovery (Maldonado et al., 2017). 


\section{REFERENCES}

Alvarez-Pellitero, P. (2008). Fish immunity and parasite infections: from innate immunity to immunoprophylactic prospects. Veterinary Immunology and Immunopathology, 126, 171-198.

Amundsen, P. A., Salonen, E., Niva, T., Gjelland, K. O., Praebel, K., Sandlund, O. T., Knudsen, R. and Bohn, T. (2012). Invader population speeds up life history during colonization. Biological Invasions, 14, 1501-1513.

Anderson, R. M. (1982). 7. Epidemiology, Blackwell Scientific Publications, Oxford \& London.

Angeloni, F., Wagemaker, N., Vergeer, P. and Ouborg, J. (2012). Genomic toolboxes for conservation biologists. Evolutionary Applications, 5, 130-143.

Anttila, P., Romakkaniemi, A., Kuusela, J. and Koski, P. (2008). Epidemiology of Gyrodactylus salaris (Monogenea) in the River Tornionjoki, a Baltic wild salmon river. Journal of Fish Diseases, 31, 373-382.

Appleby, C., Mo, T. A. and Aase, I. L. (1997). The effect of Gyrodactylus salaris (Monogenea) on the epidermis of Atlantic salmon, Salmo salar, parr in the river Batnfjordselva, Norway. Journal of Parasitology, 83, 1173-1174.

Arendt, J. D. (2015). Effects of dispersal plasticity on population divergence and speciation. Heredity, 115, 306-311.

Auld, J. and Rubio de Casas, R. (2013). The Correlated Evolution of Dispersal and MatingSystem Traits. Evolutionary Biology, 40, 185-193.

Bachmann, L., Fromm, B., de Azambuja, L. P. and Boeger, W. A. (2016). The mitochondrial genome of the egg-laying flatworm Aglaiogyrodactylus forficulatus (Platyhelminthes: Monogenoidea). Parasites \& Vectors, 9, 8.

Bakke, T. A., Cable, J. and Harris, P. D. (2007). The biology of gyrodactylid monogeneans: The "Russian-doll killers". Adv Parasitol, 64, 161-330.

Bakke, T. A., Harris, P. D. and Cable, J. (2002). Host specificity dynamics: observations on gyrodactylid monogeneans. International Journal for Parasitology, 32, 281-308.

Bakke, T. A., Harris, P. D., Hansen, H., Cable, J. and Hansen, L. P. (2004). Susceptibility of Baltic and east Atlantic salmon Salmo salar stocks to Gyrodactylus salaris (Monogenea). Diseases of Aquatic Organisms, 58, 171-177.

Bakke, T. A., Jansen, P. A. and Hansen, L. P. (1990). Differences in the host-resistance of Atlantic salmon, Salmo salar L, stocks to the monogenean Gyrodactylus salaris Malmberg, 1957. Journal of Fish Biology, 37, 577-587.

Barber, I., Mora, A. B., Payne, E. M., Weinersmith, K. L. and Sih, A. (2016). Parasitism, personality and cognition in fish. Behavioural Processes.

Beauchamp, D. A. (1990). Movements, Habitat Use, and Spawning of Arctic Grayling in a Subalpin Lake Tributary. Northwest Science, 64, 195-207.

Benton, M. J. (2009). The Red Queen and the Court Jester: Species Diversity and the Role of Biotic and Abiotic Factors Through Time. Science, 323, 728-732.

Bernhardt, B., Lampert, K. P., Leese, F., Mayer, C. and Tollrian, R. (2012). Are shoals of minnow Phoxinus phoxinus formed by close kin? Journal of Fish Biology, 80, 713-721.

Blanchet, S., Rey, O., Berthier, P., Lek, S. and Loot, G. (2009). Evidence of parasite-mediated disruptive selection on genetic diversity in a wild fish population. Molecular Ecology, 18, 1112-1123.

Blanchet, S., Rey, O. and Loot, G. (2010). Evidence for host variation in parasite tolerance in a wild fish population. Evolutionary Ecology, 24, 1129-1139.

Borgstrom, R., Museth, J. and Brittain, J. E. (2010). The brown trout (Salmo trutta) in the lake, vre Heimdalsvatn: long-term changes in population dynamics due to exploitation and the invasive species, European minnow (Phoxinus phoxinus). Hydrobiologia, 642, 81-91. 
Boulinier, T., Kada, S., Dupraz, M., Ponchon, A., Chambert, T., Garnier, R. and McCoy, K. (2016). Migration, prospecting, dispersal? What types of host movement matter for the circulation of infectious disease agents? Integrative and Comparative Biology, 56, 330E21.

Bozick, B. A. and Real, L. A. (2015). Integrating parasites and pathogens into the study of geographic range limits. Quarterly Review of Biology, 90, 361-380.

Brunner, F. S., Anaya-Rojas, J. M., Matthews, B. and Eizaguirre, C. (2017). Experimental evidence that parasites drive eco-evolutionary feedbacks. Proceedings of the National Academy of Sciences, 114, 3678-3683.

Buchmann, K. and Uldal, A. (1997). Gyrodactylus derjavini infections in four salmonids: Comparative host susceptibility and site selection of parasites. Diseases of Aquatic Organisms, 28, 201-209.

Busch, S., Dalsgaard, I. and Buchmann, K. (2003). Concomitant exposure of rainbow trout fry to Gyrodactylus derjavini and Flavobacterium psychrophilum: effects on infection and mortality of host. Veterinary Parasitology, 117, 117-122.

Cable, J., Harris, P. D. and Bakke, T. A. (2000). Population growth of Gyrodactylus salaris (Monogenea) on Norwegian and Baltic Atlantic salmon (Salmo salar) stocks. Parasitology, 121, 621-629.

Collin, H., Burri, R., Comtesse, F. and Fumagalli, L. (2013). Combining molecular evolution and environmental genomics to unravel adaptive processes of MHC class IIB diversity in European minnows (Phoxinus phoxinus). Ecology and Evolution, 3, 2568-2585.

Cone, D. K. and Dechtiar, A. 0. (1984). Gyrodactylus fryi sp (Monogenea) from esoxmasquinogy Mitchill in Ontario. Canadian Journal of Zoology-Revue Canadienne De Zoologie, 62, 1089-1090.

Criscione, C. D. (2008). Parasite co-structure: Broad and local scale approaches. ParasiteJournal De La Societe Francaise De Parasitologie, 15, 439-443.

Cunningham, C. O., Mo, T. A., Collins, C. M., Buchmann, K., Thiery, R., Blanc, G. and Lautraite, A. (2001). Redescription of Gyrodactylus teuchis Lautraite, Blanc, Thiery, Daniel \& Vigneulle, 1999 (Monogenea : Gyrodactylidae); a species identified by ribosomal RNA sequence. Systematic Parasitology, 48, 141-150.

Cusack, R. and Cone, D. K. (1986). Gyrodactylus salmonis (Yin and Sproston, 1948) parasitizing fry of Salvelinus fontinalis (Mitchill). Journal of Wildlife Diseases, 22, 209-213.

Daverdin, R. H. (1997). Dissemination of parasites through introduction of freshwater fish species: introduction of minnow (Phoxinus phoxinus) parasites to high altitude lakes with brown trout (Salmo truta), Norwegian Institute for Nature Research report, 466, 114.

Denholm, S. J., Hoyle, A. S., Shinn, A. P., Paladini, G., Taylor, N. G. H. and Norman, R. A. (2017). Predicting the Potential for Natural Recovery of Atlantic Salmon (Salmo salar L.) Populations following the Introduction of Gyrodactylus salaris Malmberg, 1957 (Monogenea) (vol 11, e0169168, 2016). Plos One, 12, 1.

Dorovskikh, G. N. and Stepanov, V. G. (2008). Change in the structure of component parasite communities with host age. Russian Journal of Ecology, 39, 215-220.

Drmanac, R. (2011). The advent of personal genome sequencing. Genetics in Medicine, 13, 188190.

Dzika, E., Maciejewska, I. W., Hoffmann, R. W. and Oidtmann, B. (2009). The Gyrodactylidae fauna of rainbow trout Oncorhynchus mykiss Walbaum 1792 in the Rogg breeding pound in Bavaria, Germany. Parasitology Research, 104, 671-676.

El Nagar, A. and MacColl, A. D. C. (2016). Parasites contribute to ecologically dependent postmating isolation in the adaptive radiation of three-spined stickleback. Proceedings of the Royal Society B-Biological Sciences, 283, 7.

El-Naggar, M. M., Cable, J., Arafa, S. Z., El-Abbassy, S. A. and Kearn, G. C. (2016). Scanning and transmission electron microscopy of the histopathological impact of Macrogyrodactylus clarii (Monogenea: Gyrodactylidae) on the gills of catfish, Clarias gariepinus. Folia Parasitologica, 63, 9. 
Elton, C. S. (1958). The ecology of invasions by animals and plants, Methuen, London.

Engering, A., Hogerwerf, L. and Slingenbergh, J. (2013). Pathogen-host-environment interplay and disease emergence. Emerging Microbes \& Infections, 2, 7.

Evans, D. H. (1993). The Physiology of fishes, CRC Press, Boca Raton, Fla.

Forseth, T., Barlaup, B. T., Finstad, B., Fiske, P., Gjøsæter, H., Falkegård, M., Hindar, A., Mo, T. A., Rikardsen, A. H., Thorstad, E. B., Vøllestad, L. A. and Wennevik, V. (2017). The major threats to Atlantic salmon in Norway. Ices Journal of Marine Science.

Forsman, A. (2014). Effects of genotypic and phenotypic variation on establishment are important for conservation, invasion, and infection biology. Proceedings of the National Academy of Sciences of the United States of America, 111, 302-307.

Fox, J. A., Dybdahl, M. F., Jokela, J. and Lively, C. M. (1996). Genetic structure of coexisting sexual and clonal subpopulations in a freshwater snail (Potamopyrgus antipodarum). Evolution, 50, 1541-1548.

Fromm, B., Burow, S., Hahn, C. and Bachmann, L. (2014). MicroRNA loci support conspecificity of Gyrodactylus salaris and Gyrodactylus thymalli (Platyhelminthes: Monogenea). International Journal for Parasitology, 44, 787-793.

Gherardi, F., Britton, J. R., Mavuti, K. M., Pacini, N., Grey, J., Tricarico, E. and Harper, D. M. (2011). A review of allodiversity in Lake Naivasha, Kenya: Developing conservation actions to protect East African lakes from the negative impacts of alien species. Biological Conservation, 144, 2585-2596.

Gregersen, F., Haugen, T. O. and Vøllestad, L. A. (2008). Contemporary egg size divergence among sympatric grayling demes with common ancestors. Ecology of Freshwater Fish, 17, 110-118.

Gum, B., Gross, R. and Kuehn, R. (2006). Discriminating the impact of recent human mediated stock transfer from historical gene flow on genetic structure of European grayling Thymallus thymallus L. Journal of Fish Biology, 69, 115-135.

Hablutzel, P. I., Gregoir, A. F., Vanhove, M. P. M., Volckaert, F. A. M. and Raeymaekers, J. A. M. (2016). Weak link between dispersal and parasite community differentiation or immunogenetic divergence in two sympatric cichlid fishes. Molecular Ecology, 25, 54515466.

Hahn, C., Fromm, B. and Bachmann, L. (2014). Comparative Genomics of Flatworms (Platyhelminthes) Reveals Shared Genomic Features of Ecto- and Endoparastic Neodermata. Genome Biology and Evolution, 6, 1105-1117.

Hahn, C., Weiss, S. J., Stojanovski, S. and Bachmann, L. (2015). Co-Speciation of the Ectoparasite Gyrodactylus teuchis (Monogenea, Platyhelminthes) and Its Salmonid Hosts. Plos One, 10, 20.

Halvorsen, O. and Daverdin, R. H. (1989). A review of the biogeography and epidemiology of Gyrodactylus salaris, Norwegian Institute for Nature Research report, 002, 1-40.

Hansen, H., Bachmann, L. and Bakke, T. A. (2003). Mitochondrial DNA variation of Gyrodactylus spp. (Monogenea, Gyrodactylidae) populations infecting Atlantic salmon, grayling, and rainbow trout in Norway and Sweden. International Journal for Parasitology, 33, 1471-1478.

Hansen, H., Bakke, T. A. and Bachmann, L. (2007a). DNA taxonomy and barcoding of monogenean parasites: lessons from Gyrodactylus. Trends in Parasitology, 23, 363-367.

Hansen, H., Bakke, T. A. and Bachmann, L. (2007b). Mitochondrial haplotype diversity of Gyrodactylus thymalli (Platyhelminthes; Monogenea): extended geographic sampling in United Kingdom, Poland, and Norway reveals further lineages. Parasitology Research, 100, 1389-1394.

Hansen, H., Cojocaru, C. D. and Mo, T. A. (2016). Infections with Gyrodactylus spp. (Monogenea) in Romanian fish farms: Gyrodactylus salaris Malmberg, 1957 extends its range. Parasites \& Vectors, 9, 10.

Hansen, H., Martinsen, L., Bakke, T. A. and Bachmann, L. (2006). The incongruence of nuclear and mitochondrial DNA variation supports conspecificity of the monogenean parasites Gyrodactylus salaris and G. thymalli. Parasitology, 133, 639-650. 
Hanski, I. (1999). Metapopulation ecology, Oxford University Press, Oxford.

Harris, P. D. (1983). Studies on the biology of the Gyrodactyloidea (Monogenea). Ph.D. thesis pp xiii, 312 s. University of London.

Harris, P. D., Shinn, A. P., Cable, J. and Bakke, T. A. (2004). Nominal species of the genus Gyrodactylus von Nordmann 1832 (Monogenea : Gyrodactylidae), with a list of principal host species. Systematic Parasitology, 59, 1-27.

Harris, P. D., Shinn, A. P., Cable, J., Bakke, T. A. and Bron, J. (2008). GyroDb: gyrodactylid monogeneans on the web. Trends in Parasitology, 24, 109-111.

Haugen, T. O. and Vøllestad, L. A. (2000). Population differences in early life-history traits in grayling. Journal of Evolutionary Biology, 13, 897-905.

Heger, T. and Jeschke, J. M. (2014). The enemy release hypothesis as a hierarchy of hypotheses. Oikos, 123, 741-750.

Hellmann, I., Mang, Y., Gu, Z. P., Li, P., de la Vega, F. M., Clark, A. G. and Nielsen, R. (2008). Population genetic analysis of shotgun assemblies of genomic sequences from multiple individuals. Genome Research, 18, 1020-1029.

Hesthagen, T. and Sandlund, 0. T. (2004). Fish distribution in a mountain area in southeastern Norway: human introductions overrule natural immigration. Hydrobiologia, 521, 49-59.

Hewitt, G. M. (1996). Some genetic consequences of ice ages, and their role in divergence and speciation. Biological Journal of the Linnean Society, 58, 247-276.

Holmen, J. (2013). The Eurasian minnow: post-glacial dispersal history and recent invasion patterns in Norway. In Department of Biology, Ph.D. thesis pp. 170. University of Oslo.

Holsinger, K. E. (2010). Next generation population genetics and phylogeography. Molecular Ecology, 19, 2361-2363.

Holsinger, K. E. and Weir, B. S. (2009). Genetics in geographically structured populations: defining, estimating and interpreting F $_{\text {ST. Nature Reviews Genetics, 10, 639-650. }}$

Hopper, K. R. (1999). Risk-spreading and bet-hedging in insect population biology. Annual review of entomology, 44, 535.

Huitfeldt-Kaas (1918). Ferskvandsfiskenes utbredelse og indvandring i Norge, med et tillæg om krebsen. in Norwegian (Distribution and post-glacial colonisation of freshwater fishes in Norway, including the cray fish.). Centraltrykkeriet, Kristiania (Oslo).

Huyse, T., Oeyen, M., Larmuseau, M. H. D. and Volckaert, F. A. M. (2017). Co-phylogeographic study of the flatworm Gyrodactylus gondae and its goby host Pomatoschistus minutus. Parasitology International, 66, 119-125.

Huyse, T., Poulin, R. and Theron, A. (2005). Speciation in parasites: a population genetics approach. Trends Parasitol., 21, 469-475.

Huyse, T. and Volckaert, F. A. M. (2005). Comparing host and parasite phylogenies: Gyrodactylus flatworms jumping from goby to goby. Systematic Biology, 54, 710-718.

Hytterød, S., Lie Linaker, M., Hansen, H., Mo, T. A. and Tavornpanich, S. (2014). The surveillance programme for Gyrodactylus salaris in Atlantic salmon and rainbow trout in Norway 2013. Norwegian Veterinary Institute Oslo, Annual Report, 1-7.

Ieshko, E., Barskaya, Y., Parshukov, A., Lumme, J. and Khlunov, O. (2016). Occurrence and morphogenetic characteristics of Gyrodactylus (Monogenea: Gyrodactylidae) from a rainbow trout farm (Lake Ladoga, Russia). Acta Parasitologica, 61, 151-157.

Jansen, P. A. and Bakke, T. A. (1991). Temperature-dependent reproduction and survival of Gyrodactylus salaris Malmberg, 1957 (Platyhelminthes - Monogenea) on Atlantic salmon (Salmo salar L). Parasitology, 102, 105-112.

Jarne, P. and Theron, A. (2001). Genetic structure in natural populations of flukes and snails: a practical approach and review. Parasitology, 123, S27-S40.

Jensen, A. J., Hansen, L. P., Johnsen, B. O. and Karlsson, S. (2017). Rapid evolution of genetic and phenotypic divergence in Atlantic salmon following the colonisation of two new branches of a watercourse. Genetics Selection Evolution, 49, 1-12.

Johnsen, B. O. and Jensen, A. J. (1986). Infestations of Atlantic Salmon, Salmo salar, by Gyrodactylus salaris in Norwegian Rivers. Journal of Fish Biology, 29, 233-241. 
Johnsen, B. O. and Jensen, A. J. (1991). The Gyrodactylus story in Norway. Aquaculture, 98, 289302.

Johnsen, B. O., Moekkelgjerd, P. I., Jensen, A.J. (1999). The parasite Gyrodactylus salaris on salmon parr in Norwegian rivers, satus at the beginning of 2000. Norwegian Institute for Nature Research report, 617 1-129.

Junge, C., Vøllestad, L. A., Barson, N. J., Haugen, T. O., Otero, J., Saetre, G. P., Leder, E. H. and Primmer, C. R. (2011). Strong gene flow and lack of stable population structure in the face of rapid adaptation to local temperature in a spring-spawning salmonid, the European grayling (Thymallus thymallus). Heredity, 106, 460-471.

Kania, P. W., Jorgensen, T. R. and Buchmann, K. (2007). Differentiation between a pathogenic and a non-pathogenic form of Gyrodactylus salaris using PCR-RFLP. Journal of Fish Diseases, 30, 123-126.

Kennedy, C. R. (1978). Parasite fauna of resident char (Salvelinus alpinus) from Arctic islands, with special reference to Bear Island. Journal of Fish Biology, 13, 457-466.

Kimura, M. (1980). A simple method for estimating evolutionary rates of base substitutions through comparative studies of nucleotide sequences. Journal of Molecular Evolution, 16, 111-120.

Koskinen, M. T., Haugen, T. O. and Primmer, C. R. (2002a). Contemporary fisherian lifehistory evolution in small salmonid populations. Nature, 419, 826-830.

Koskinen, M. T., Knizhin, I., Primmer, C. R., Schlotterer, C. and Weiss, S. (2002b). Mitochondrial and nuclear DNA phylogeography of Thymallus spp. (grayling) provides evidence of ice-age mediated environmental perturbations in the world's oldest body of fresh water, Lake Baikal. Molecular Ecology, 11, 2599-2611.

Koskinen, M. T., Nilsson, J., Veselov, A. J., Potutkin, A. G., Ranta, E. and Primmer, C. R. (2002c). Microsatellite data resolve phylogeographic patterns in European grayling, Thymallus thymallus, Salmonidae. Heredity, 88, 391-401.

Koskinen, M. T., Ranta, E., Piironen, J., Veselov, A., Titov, S., Haugen, T. O., Nilsson, J., Carlstein, M. and Primmer, C. R. (2000). Genetic lineages and postglacial colonization of grayling (Thymallus thymallus, Salmonidae) in Europe, as revealed by mitochondrial DNA analyses. Molecular Ecology, 9, 1609-1624.

Kristiansen, H. and Døving, K. B. (1996). The migration of spawning stocks of grayling Thymallus thymallus, in Lake Mjosa, Norway. Environmental Biology of Fishes, 47, 43-50.

Kudlai, O., Oros, M., Kostadinova, A. and Georgieva, S. (2017). Exploring the diversity of Diplostomum (Digenea: Diplostomidae) in fishes from the River Danube using mitochondrial DNA barcodes. Parasites \& Vectors, 10.

Kumar, S., Stecher, G. and Tamura, K. (2016). MEGA7: Molecular Evolutionary Genetics Analysis Version 7.0 for Bigger Datasets. Molecular Biology and Evolution, 33, 18701874.

Kuusela, J., Holopainen, R., Meinilä, M., Anttila, P., Koski, P., Ziętara, M. S., Veselov, A., Primmer, C. R. and Lumme, J. (2009). Clonal structure of salmon parasite Gyrodactylus salaris on a coevolutionary gradient on Fennoscandian salmon (Salmo salar). Ann. Zool. Fennici, 46, 21-33.

Kuusela, J., Ziętara, M. S. and Lumme, J. (2007). Hybrid origin of Baltic salmon-specific parasite Gyrodactylus salaris: a model for speciation by host switch for hemiclonal organisms. Molecular Ecology, 16, 5234-5245.

Lau, J. A. and Schultheis, E. H. (2015). When two invasion hypotheses are better than one. New Phytologist, 205, 958-960.

Leal, E., Granja, A. G., Ziętara, C. and Tafalla, C. (2016). Distribution of T Cells in Rainbow Trout (Oncorhynchus mykiss) Skin and Responsiveness to Viral Infection. Plos One, 11, 18.

Lester, R. J. G. (1972). Attachment of Gyrodactylus to Gastosteus and host response. Journal of Parasitology, 58, 717-722. 
Lindqvist, C., Plaisance, L., Bakke, T. A. and Bachmann, L. (2007). Mitochondrial DNA variation of a natural population of Gyrodactylus thymalli (Monogenea) from the type locality River Hnilec, Slovakia. Parasitology Research, 101, 1439-1442.

Liu, Y. C., Cortesi, P., Double, M. L., MacDonald, W. L. and Milgroom, M. G. (1996). Diversity and multilocus genetic structure in populations of Cryphonectria parasitica. Phytopathology, 86, 1344-1351.

Lumme, J., Anttila, P., Rintamäki, P., Koski, P. and Romakkaniemi, A. (2016). Genetic gradient of a host-parasite pair along a river persisted ten years against physical mobility: Baltic Salmo salar vs. Gyrodactylus salaris. Infection Genetics and Evolution, $\mathbf{4 5}$, 33-39.

Maldonado, L. L., Assis, J., Araujo, F. M. G., Salim, A. C. M., Macchiaroli, N., Cucher, M., Camicia, F., Fox, A., Rosenzvit, M., Oliveira, G. and Kamenetzky, L. (2017). The Echinococcus canadensis (G7) genome: a key knowledge of parasitic platyhelminth human diseases. BMC Genomics, 18, 23.

Malmberg, G. and Malmberg, M. (1993). Species of Gyrodactylus (Platyhelminthes, Monogenea) on Salmonids in Sweden. Fisheries Research, 17, 59-68.

Marcogliese, D. J. and Cone, D. K. (1996). On the distribution and abundance of eel parasites in Nova Scotia: Influence of pH. Journal of Parasitologi, 82, 389-399.

Matějusová, I., Morand, S. and Gelnar, M. (2000). Nestedness in assemblages of gyrodactylids (Monogenea : Gyrodactylidea) parasitising two species of cyprinid - with reference to generalists and specialists. International Journal for Parasitology, 30, 1153-1158.

Mazè-Guilmo, E., Blanchet, S., McCoy, K. D. and Loot, G. (2016). Host dispersal as the driver of parasite genetic structure: a paradigm lost? Ecology Letters, 19, 336-347.

McCoy, K. D., Beis, P., Barbosa, A., Cuervo, J. J., Fraser, W. R., Gonzalez-Solis, J., Jourdain, E., Poisbleau, M., Quillfeldt, P., Leger, E. and Dietrich, M. (2012). Population genetic structure and colonisation of the western Antarctic Peninsula by the seabird tick Ixodes uriae. Marine Ecology Progress Series, 459, 109-120.

McCoy, K. D., Boulinier, T. and Tirard, C. (2005). Comparative host-parasite population structures: disentangling prospecting and dispersal in the black-legged kittiwake Rissa tridactyla. Molecular Ecology, 14, 2825-2838.

Meinilä, M., Kuusela, J., Ziętara, M. S. and Lumme, J. (2004). Initial steps of speciation by geographic isolation and host switch in salmonid pathogen Gyrodactylus salaris (Monogenea : Gyrodactylidae). International Journal for Parasitology, 34, 515-526.

Meirmans, P. G. and Hedrick, P. W. (2011). Assessing population structure: $\mathrm{F}_{\mathrm{ST}}$ and related measures. Molecular Ecology Resources, 11, 5-18.

Mills, C. A. (1988). The effect of extreme northerly climatic conditions on lifehistory of the minnow, Phoxinus phoxinus (L.). Journal of Fish Biology, 33, 545-561.

Mills, L. S. (2007). Conservation of wildlife populations: demography, genetics, and management, Blackwell, Oxford.

Mitchell, C. E. and Power, A. G. (2003). Release of invasive plants from fungal and viral pathogens. Nature, 421, 625-627.

Mo, T. A. (1992). Seasonal variations in the prevalence and infestation intensity of Gyrodactylus salaris Malmberg, 1957 (Monogenea: Gyrodactylidae) on Atlantic salmon parr, Salmo salar L., in the River Batnfjordselva, Norway. Journal of Fish Biology, 41, 697-707.

Mo, T. A. (1994). Status of Gyrodactylus salaris problems and research in Norway, Samara Publishing Limited., Otley, Yorkshire.

Mo, T. A. and Appleby, C. (1990). A special technique for studyng haptoral sclerites of monogeneans. Systematic Parasitology, 17, 103-108.

Museth, J., Borgstrom, R. and Brittain, J. E. (2010). Diet overlap between introduced European minnow (Phoxinus phoxinus) and young brown trout (Salmo trutta) in the lake, vre Heimdalsvatn: a result of abundant resources or forced niche overlap? Hydrobiologia, 642, 93-100. 
Museth, J., Hesthagen, T., Sandlund, O. T., Thorstad, E. B. and Ugedal, 0. (2007). The history of the minnow Phoxinus phoxinus (L.) in Norway: from harmless species to pest. Journal of Fish Biology, 71, 184-195.

Nentwing, W. (2007). Biological Invasions, Springer Berlin Heidelberg, Berlin, Heidelberg, Berlin, Heidelberg.

Nieberding, C. M., Durette-Desset, M. C., Vanderpoorten, A., Casanova, J. C., Ribas, A., Deffontaine, V., Feliu, C., Morand, S., Libois, R. and Michaux, J. R. (2008). Geography and host biogeography matter for understanding the phylogeography of a parasite. Molecular Phylogenetics and Evolution, 47, 538-554.

Nieberding, C. M. and Olivieri, I. (2007). Parasites: proxies for host genealogy and ecology? Trends in Ecology \& Evolution, 22, 156-165.

Northcote, T. G. (1995). Comparative biology and management of Arctic and European grayling (Salmonidae, Thymallus). Reviews in Fish Biology and Fisheries, 5, 141-194.

Olivieri, I., Michalakis, Y. and Gouyon, P. H. (1995). Metapopulation genetics and the evolution of dispersal. American Naturalist, 146, 202-228.

Olstad, K., Robertsen, G., Bachmann, L. and Bakke, T. A. (2007). Variation in host preference within Gyrodactylus salaris (Monogenea): an experimental approach. Parasitology, 134, 589-597.

Paladini, G., Gustinelli, A., Fioravanti, M. L., Hansen, H. and Shinn, A. P. (2009). The first report of Gyrodactylus salaris Malmberg, 1957 (Platyhelminthes, Monogenea) on Italian cultured stocks of rainbow trout (Oncorhynchus mykiss Walbaum). Veterinary Parasitology, 165, 290-297.

Paladini, G., Hansen, H., Williams, C. F., Taylor, N. G. H., Rubio-Mejia, O. L., Denholm, S. J., Hytterod, S., Bron, J. E. and Shinn, A. P. (2015). Reservoir hosts for Gyrodactylus salaris may play a more significant role in epidemics than previously thought. Parasites \& Vectors, 7, 576.

Parker, I. M., Simberloff, D., Lonsdale, W. M., Goodell, K., Wonham, M., Kareiva, P. M., Williamson, M. H., Von Holle, B., Moyle, P. B., Byers, J. E. and Goldwasser, L. (1999). Impact: toward a framework for understanding the ecological effects of invaders. Biological Invasions, 1, 3-19.

Peeler, E. J., Oidtmann, B. C., Midtlyng, P. J., Miossec, L. and Gozlan, R. E. (2011). Non-native aquatic animals introductions have driven disease emergence in Europe. Biological Invasions, 13, 1291-1303.

Perrings, C., Dehnen-Schmutz, K., Touza, J. and Williamson, M. (2005). How to manage biological invasions under globalization. Trends in Ecology \& Evolution, 20, 212-215.

Pettersen, R. A., Hytterød, S., Mo, T. A., Poléo, A. B. S., G., H. A., Flodmark, L. E. W., Høgberget, R., Olsen, N., Kjøstnes, A. J., Øxnevad, S. A., Håvardstun, J., Kristensen, T., Sandodden, R., Moen, A. and Lydersen, E. (2006a). Chemical treatment against Gyrodactylus salaris in Lærdalselva 2005, Norwegian Institute for Water Research report, 5169-2006, 1-24.

Pettersen, R. A., Vøllestad, L. A., Flodmark, L. E. W. and Poléo, A. B. S. (2006b). Effects of aqueous aluminium on four fish ectoparasites. Science of the Total Environment, 369, 129-138.

Pickering, A. D. and Christie, P. (1980). Sexual differences in the incidence and severity of ectoparasitic infestation of the Brown trout, Salmo trutta L. Journal of Fish Biology, 16, 669-683.

Pimentel, D., Zuniga, R. and Morrison, D. (2005). Update on the environmental and economic costs associated with alien-invasive species in the United States. Ecological Economics, 52, 273-288.

Poléo, A. B. S., Schjolden, J., Hansen, H., Bakke, T. A., Mo, T. A., Rosseland, B. O. and Lydersen, E. (2004). The effect of various metals on Gyrodactylus salaris (Platyhelminthes, Monogenea) infections in Atlantic salmon (Salmo salar). Parasitology, 128, 169-177. 
Pool, J. E., Hellmann, I., Jensen, J. D. and Nielsen, R. (2010). Population genetic inference from genomic sequence variation. Genome Research, 20, 291-300.

Poulin, R. (2007). Evolutionary ecology of parasites. Second edition, Princeton University Press.

Poulin, R. and Morand, S. (2004). Parasite biodiversity, Smithsonian Books.

Price, P. W. (1977). General concepts on the evolutionary biology of parasites. Evolution, 31, 405-420.

Rahel, F. J. and Olden, J. D. (2008). Assessing the effects of climate change on aquatic invasive species. Conservation Biology, 22, 521-533.

Rahn, A. K., Krassmann, J., Tsobanidis, K., MacColl, A. D. C. and Bakker, T. C. M. (2016). Strong neutral genetic differentiation in a host, but not in its parasite. Infection Genetics and Evolution, 44, 261-271.

Refseth, U. H., Nesbø, C. L., Stacy, J. E., Vøllestad, L. A., Fjeld, E. and Jakobsen, K. S. (1998). Genetic evidence for different migration routes of freshwater fish into Norway revealed by analysis of current perch (Perca fluviatilis) populations in Scandinavia. Molecular Ecology, 7, 1015-1027.

Richards, E. L., van Oosterhout, C. and Cable, J. (2012). Interactions between males guppies facilitates the transmission of the monogenean ectoparasite Gyrodactylus turnbulli. Exp. Parasitol., 132, 483-486.

Robertsen, G., Hansen, H., Bachmann, L. and Bakke, T. A. (2007). Arctic charr (Salvelinus alpinus) is a suitable host for Gyrodactylus salaris (Monogenea, Gyrodactylidae) in Norway. Parasitology, 134, 257-267.

Robertson, S., Bradley, J. E. and Maccoll, A. D. C. (2017). No evidence of local adaptation of immune responses to Gyrodactylus in three-spined stickleback (Gasterosteus aculeatus). Fish and Shellfish Immunology, 60, 275-281.

Roff, D. A. (1994). Habitat persistence and the evolution of wing dimorphism in insects. American Naturalist, 144, 772-798.

Rokicka, M., Lumme, J. and Ziętara, M. S. (2007). Identification of Gyrodactylus ectoparasites in Polish salmonid farms by PCR-RFLP of the nuclear ITS segment of ribosomal DNA (Monogenea, Gyrodactylidae). Acta Parasitologica, 52, 185-195.

Ronce, 0. (2007). How does it feel to be like a rolling stone? Ten questions about dispersal evolution. In Annual Review of Ecology Evolution and Systematics, 38, 231-253. Annual Reviews, Palo Alto.

Rousset, F. and Gandon, S. (2002). Evolution of the distribution of dispersal distance under distance-dependent cost of dispersal. Journal of Evolutionary Biology, 15, 515-523.

Rousset, F. and Ronce, 0. (2004). Inclusive fitness for traits affecting metapopulation demography. Theoretical Population Biology, 65, 127-141.

Salte, R., Bentsen, H. B., Moen, T., Tripathy, S., Bakke, T. A., Odegard, J., Omholt, S. and Hansen, L. P. (2010). Prospects for a genetic management strategy to control Gyrodactylus salaris infection in wild Atlantic salmon (Salmo salar) stocks. Canadian Journal of Fisheries and Aquatic Sciences, 67, 121-129.

Smallbone, W., Van Oosterhout, C. and Cable, J. (2016). The effects of inbreeding on disease susceptibility: Gyrodactylus turnbulli infection of guppies, Poecilia reticulata. Experimental Parasitology, 167, 32-37.

Soleng, A. and Bakke, T. A. (1997). Salinity tolerance of Gyrodactylus salaris (Platyhelminthes, Monogenea): laboratory studies. Canadian Journal of Fisheries and Aquatic Sciences, 54, 1837-1845.

Soleng, A. and Bakke, T. A. (2001). The susceptibility of grayling (Thymallus thymallus) to experimental infections with the monogenean Gyrodactylus salaris. International Journal for Parasitology, 31, 793-797.

Soleng, A., Polèo, A. B. S., Alstad, N. E. W. and Bakke, T. A. (1999). Aqueous aluminium eliminates Gyrodactylus salaris (Platyhelminthes, Monogenea) infections in Atlantic salmon. Parasitology, 119, 19-25.

Soleng, A., Polèo, A. B. S. and Bakke, T. A. (2005). Toxicity of aqueous aluminium to the ectoparasitic monogenean Gyrodactylus salaris. Aquaculture, 250, 616-620. 
Stenseth, N. C. and Lidicker, W. Z. (1992). Animal dispersal : small mammals as a model, Chapman \& Hall, London.

Sterud, E. (1999). Parasites at Norwegian freshwater fish, Norsk zoologisk forening report, 7, 122 , Oslo.

Sterud, E., Harris, P. D. and Bakke, T. A. (1998). The influence of Gyrodactylus salaris Malmberg, 1957 (Monogenea) on the epidermis of Atlantic salmon, Salmo salar L., and brook trout, Salvelinus fontinalis (Mitchill): experimental studies. Journal of Fish Diseases, 21, 257-263.

Sterud, E., Mo, T. A., Collins, C. M. and Cunningham, C. 0. (2002). The use of host specificity, pathogenicity, and molecular markers to differentiate between Gyrodactylus salaris Malmberg, 1957 and G. thymalli Zitnan, 1960 (Monogenea : Gyrodactylidae). Parasitology, 124, 203-213.

Stradmeyer, L., Verspoor, E. and Nielsen, J. L. (2007). The Atlantic salmon : genetics, conservation and management, Blackwell, Oxford.

Teske, P. R., Golla, T. R., Sandoval-Castillo, J., Emami-Khoyi, A., van Der Lingen, C. D., Von Der Heyden, S., Chiazzari, B., Jansen van Vuuren, B. and Beheregaray, L. B. (2018). Mitochondrial DNA is unsuitable to test for isolation by distance. Scientific Reports, 8.

Torchin, M. E., Lafferty, K. D., Dobson, A. P., McKenzie, V. J. and Kuris, A. M. (2003). Introduced species and their missing parasites. Nature, 421, 628-630.

Verspoor, E., Consuegra, S., Fridjonsson, O., Hjorleifsdottir, S., Knox, D., Olafsson, K., Tompsett, S., Wennevik, V. and de Leaniz, C. G. (2012). Regional mtDNA SNP differentiation in European Atlantic salmon (Salmo salar): an assessment of potential utility for determination of natal origin. Ices Journal of Marine Science, 69, 1625-1636.

Voegeli, B., Saladin, V., Wegmann, M. and Richner, H. (2012). Parasites as mediators of heterozygosity-fitness correlations in the Great Tit (Parus major). Journal of Evolutionary Biology, 25, 584-590.

von Sieboldt, C. (1849). Gyrodactylus, ein ammenartiges Wesen. Zeitschrift für wissenschaftliche Zoologie, 1, 347.

Wells, P. R. and Cone, D. K. (1990). Experimental studies on the effect of Gyrodactylus colemansis and Gyrodactylus salmonis (Monogenea) on density of mucous cells in the epidermis of fry of Oncorhynchus mykiss. Journal of Fish Biology, 37, 599-603.

Winger, A. C., Kristoffersen, R., Siikavuopio, S. I. and Knudsen, R. (2009). Experiments to test if allopatric Salvelinus alpinus are suitable year-round hosts of Gyrodactylus salaris (Monogenea). Journal of Fish Biology, 74, 1476-1486.

Winger, A. C., Primicerio, R., Kristoffersen, R., Siikavuopio, S. I. and Knudsen, R. (2008). Gyrodactylus salaris infecting allopatric Arctic charr Salvelinus alpinus fry: an experimental study of host survival. Journal of Fish Biology, 73, 2198-2209.

Woolhouse, M. E. J., Haydon, D. T. and Antia, R. (2005). Emerging pathogens: the epidemiology and evolution of species jumps. Trends in Ecology \& Evolution, 20, 238244.

Woolhouse, M. E. J., Taylor, L. H. and Haydon, D. T. (2001). Population biology of multihost pathogens. Science (Washington D C), 292, 1109-1112.

Woolhouse, M. E. J., Webster, J. P., Domingo, E., Charlesworth, B. and Levin, B. R. (2002). Biological and biomedical implications of the co-evolution of pathogens and their hosts. Nature Genetics, 32, 569-577.

Wright, S. (1943). Isolation by distance. Genetics, 28, 114-138.

Xu, D. H., Shoemaker, C. A. and Klesius, P. H. (2007). Evaluation of the link between gyrodactylosis and streptococcosis of Nile tilapia, Oreochromis niloticus (L.). Journal of Fish Diseases, 30, 233-238.

Ziętara, M. S., Huyse, T., Lumme, J. and Volckaert, F. A. (2002). Deep divergence among subgenera of Gyrodactylus inferred from rDNA ITS region. Parasitology, 124, 39-52.

Zuk, M. and Stoehr, A. M. (2002). Immune defense and host life history. American Naturalist, 160, 9-22. 
Østbye, K., Bernatchez, L., Næsje, T. F., Himberg, K. J. M. and Hindar, K. (2005). Evolutionary history of the European whitefish Coregonus lavaretus (L.) species complex as inferred from mtDNA phylogeography and gill-raker numbers. Molecular Ecology, 14, 43714387.

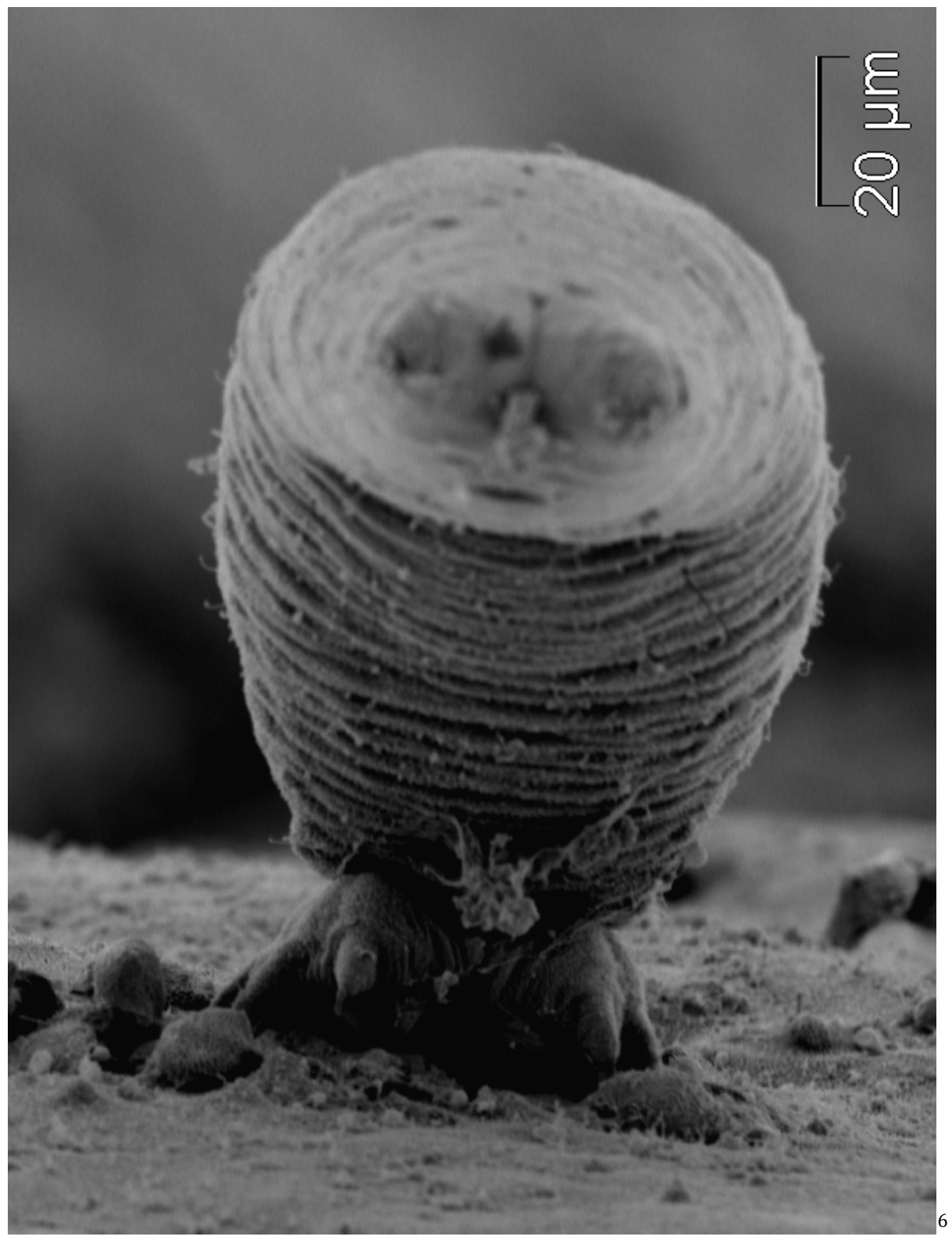

${ }^{6}$ A scanning electron microscope pictures of Gyrodactylus derjavinoides on brown trout (Salmo trutta). Photo: Ruben A. Pettersen 


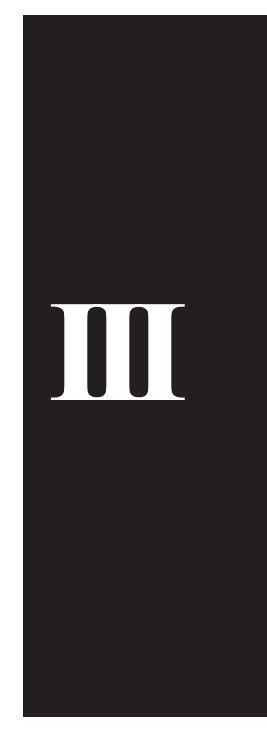





\title{
Gyrodactylus spp. diversity in native and introduced minnow (Phoxinus phoxinus) populations: no support for "the enemy release" hypothesis
}

Ruben Alexander Pettersen ${ }^{1 *}$, Kjartan Østbye ${ }^{1,2}$, Johannes Holmen ${ }^{1}$, Leif Asbjørn Vøllestad ${ }^{1}$ and Tor Atle Mo $^{3}$

\begin{abstract}
Background: Translocation of native species and introduction of non-native species are potentially harmful to the existing biota by introducing e.g. diseases, parasites and organisms that may negatively affect the native species. The enemy release hypothesis states that parasite species will be lost from host populations when the host is introduced into new environments.
\end{abstract}

Methods: We tested the enemy release hypothesis by comparing 14 native and 29 introduced minnow (Phoxinus phoxinus) populations in Norway with regard to the ectoparasitic Gyrodactylus species community and load (on caudal fin). Here, we used a nominal logistic regression on presence/absence of Gyrodactylus spp. and a generalized linear model on the summed number of Gyrodactylus spp. on infected populations, with individual minnow heterozygosity (based on 11 microsatellites) as a covariate. In addition, a sample-based rarefaction analysis was used to test if the Gyrodactylus-species specific load differed between native and introduced minnow populations. An analysis of molecular variance was performed to test for hierarchical population structure between the two groups and to test for signals of population bottlenecks the two-phase model in the Wilcoxon signed-rank test was used. To test for demographic population expansion events in the introduced minnow population, we used the kg-test under a stepwise mutation model.

Results: The native and introduced minnow populations had similar species compositions of Gyrodactylus, lending no support to the enemy release hypothesis. The two minnow groups did not differ in the likelihood of being infected with Gyrodactylus spp. Considering only infected minnow populations it was evident that native populations had a significantly higher mean abundance of Gyrodactylus spp. than introduced populations. The results showed that homozygotic minnows had a higher Gyrodactylus spp. infection than more heterozygotic hosts. Using only infected individuals, the two minnow groups did not differ in their mean number of Gyrodactylus spp. However, a similar negative association between heterozygosity and abundance was observed in the native and introduced group. There was no evidence for demographic bottlenecks in the minnow populations, implying that introduced populations retained a high degree of genetic variation, indicating that the number of introduced minnows may have been large or that introductions have been happening repeatedly. This could partly explain the similar species composition of Gyrodactylus in the native and introduced minnow populations.

\footnotetext{
* Correspondence: rubenap@ibv.uio.no

${ }^{1}$ Center for Ecological and Evolutionary Synthesis (CEES), Department of

Biosciences, University of Oslo, P. O. Box 1066 Blindern, NO-0316, Oslo,

Norway

Full list of author information is available at the end of the article
} 
(Continued from previous page)

Conclusions: In this study it was observed that native and introduced minnow populations did not differ in their species community of Gyrodactylus spp., lending no support to the enemy release hypothesis. A negative association between individual minnow host heterozygosity and the number of Gyrodactylus spp. was detected. Our results suggest that the enemy release hypothesis does not necessarily limit fish parasite dispersal, further emphasizing the importance of invasive fish species dispersal control.

\section{Background}

Anthropogenic translocation of species between ecosystems occurs worldwide at an increasing rate [1]. Some species that are introduced into new environments become invasive, imposing major negative ecological effects on the native biota [2] with concomitant economic costs for the society [3-6]. Introduced species may also act as vectors for new parasites and diseases that may infect native hosts [7]. Transmission of non-native parasite species may lead to large population-dynamic effects [8]. Noteworthy examples are the introduction of the monogenean Gyrodactylus salaris Malmberg, 1957 [9] into Norwegian rivers with subsequent dramatic decline in the native Atlantic salmon (Salmo salar L.) populations [10] and the crayfish plague (Aphanomyces astaci Schikora, 1906), a parasite that has been introduced to Norwegian watercourses and causes mass-mortalities in European crayfish (Astacus astacus L.) populations [11]. In these cases, strong and visible effects are evident, but often the effects of introduced parasites are difficult to observe [12].

Freshwater fish are commonly transported outside their native distribution area; this potentially leads to a loss of native fish species and that the fish communities become more similar (sometimes called species homogenization)[13, 14]. The minnow (Phoxinus phoxinus L.) is distributed from Urals in the east to Europe in the west. In Norway, the minnow's natural distribution is limited to the northern and southeastern parts [15]. During the last decades, new minnow populations have been established due to human activities such as fishing with live bait, stocking (intentional and non-intentional), and reorganization of waterways [16]. Genetic studies suggest that both short- and long-distance translocations of minnows have occurred between Norwegian watercourses [17, 18]. Several species of ectoparasites of the genera Gyrodactylus have been reported from minnow in Europe [9, 19, 20]. The diversity of Gyrodactylus spp. on Norwegian minnow is not well known, but earlier studies indicate that up to five Gyrodactylus species can be found [21]. The Gyrodactylus fauna in Norway is depauperate compared to the rest of Europe [22]. Gyrodactylus spp. often exhibit a high degree of host-specificity and a direct life cycle where transmission typically takes place after direct contact with a new host [23]. These traits make Gyrodactylus spp. particularly tractable for parasite studies, as it is not necessary to take infracommunities from intermediate hosts into consideration [24]. The effects of Gyrodactylus spp. on minnow hosts are not known, but based on other Gyrodactylus - host systems it is reasonable to assume they impose negative fitness impacts [25].

The "enemy release hypothesis" (ERH) states that introduced species lose some of their natural enemies such as pathogens and parasites in the new environment [26, 27]. This will provide a fitness advantage as less energy is used to respond to the parasites and more can be allocated to growth and reproduction. Comparing native and introduced plant species, Mitchell and Power [28] found that introduced plants harboured less fungi and virus species than plants in their native habitats. Further, Torchin et al. [29] compared 26 host taxa (molluscs, crustaceans, fishes, birds, mammals, amphibians and reptiles) and showed that introduced species had half the number of species of parasites compared to the native species. A comparison of 176 different studies addressing the enemy release hypothesis found almost as many studies in support (36\%) as questioning the hypothesis (43\%) [30]. There is also some support for the ERH-hypothesis in freshwater fish [31-34]. However, few studies have addressed this topic at the population level. Halvorsen [35] hypothesized that local movement of fish between neighbouring water bodies would similarly disseminate their parasites, assuming that ecological conditions were similar. Under this hypothesis, the prediction would be that transport of individuals between closely located water bodies would lead to a more similar parasite fauna in native and introduced hosts than if hosts are introduced to more geographically distant locations. Alternatively, the number of parasites might increase in introduced populations compared to native populations by acquiring new parasites in the new environments from resident hosts [36, 37].

There are several factors that can affect the abundance of and resistance to parasites in host species, both in native and introduced populations. One such factor is heterozygosity, measured by neutral genetic markers, which is hypothesized to be associated with fitness (review by Chapman et al. [38]), and fitness-related traits such as resistance to parasite infections [39]. The assumption is 
that a genetically diverse host has a more robust immune system to handle parasite infections as it holds a larger diversity of anti-parasite specific genes [40, 41] Several studies on fish species have documented that selection acts on MHC genes related to e.g. monogenean infection (reviewed by Alvarez-Pellitero, [42]). Also, demographic bottlenecks during introduction to the new environments may result in reduced genetic diversity in host and/or parasite population, putatively affecting persistence and fitness in the new environment [43].

The main aim of this study was to test the enemy release hypothesis using a dataset on native and introduced minnow populations in Norway. First we tested if the diversity of Gyrodactylus species differed between native and introduced minnow populations. Then we tested for variation in prevalence (i.e. presence and absence) and intensity of Gyrodactylus (species pooled) between native and introduced minnow. By estimating multilocus heterozygosity of the minnow hosts using a set of eleven neutral microsatellites we tested for association between individual heterozygosity and intensity. We also tested if the transplanted minnow populations had gone through demographic bottlenecks and subsequent population expansions, which potentially could explain some of our results.

\section{Methods}

\section{Study area and sampling}

The sampling sites were selected to cover most of the distribution of native [15] and introduced [17, 44] minnow populations in Norway (Fig. 1, Table 1). The minnow populations, both native and introduced, are localized geographically far apart, usually in different watersheds. It is thus highly unlikely that there is or has been natural dispersal between the different minnow populations. The native minnow populations were all found below the upper marine limit, this limit is regarded as limiting the dispersal of minnow. The introduced minnow populations were mainly located in mountainous regions in southern Norway, and all above the upper marine limit [16]. Potentially, non-native minnow could have been introduced into native populations, leading to native and non-native minnow living in sympatry. However, a detailed study of the genetic population structure of minnow in many of these lakes indicated that this was not the case [17]. The Norwegian freshwater fish fauna is depauperate and in most populations only one or two species are present. Details on the composition of fish species at the different sampling locations is presented in Additional file 1. Brown trout (Salmo trutta) was the only species present at all sampling sites.

The water temperature regimes may differ between native minnow populations located at lower altitudes below the upper marine limit compared with introduced minnow usually found in high mountain lakes. Based on recent genetic studies, the newly founded minnow populations seem to have a diverse origin, some originating from fish transported at local scales and some transported at regional (European) scales [17, 18].

A total of 1278 minnow were randomly sampled from 43 populations (14 native; 29 introduced) during the years of 1997-2003, mainly during August and September (Fig. 1, Table 1). The introduced populations were identified based on their elevation above sea level (i.e. being situated outside the main natural distribution area of the minnow in Norway) as well as not having prior records of minnow occurrence [15, 44, 45]. However, the original sources of the introduced minnow populations are unknown, precluding a direct comparison between introduced and source populations.

Minnows were captured in small rivers/streams and in lakes close to the shoreline, using backpack electric fishing equipment. After capture, all minnows were immediately euthanized and stored on $96 \%$ ethanol for later analysis. However, in some cases only the caudal fin was preserved in ethanol for later analysis (see description below). There is no information available on the density of minnow in the different lakes.

\section{Gyrodactylus spp. identification}

In the laboratory, the caudal fin was excised from each fish that had been preserved as a total individual. These excised caudal fins and the caudal fins that were excised and conserved in the field were then investigated in detail. The caudal fin was chosen in order to utilize the total material of minnow samples. Thus we here assume that parasite counts on the caudal fin are representative for the total Gyrodactylus spp. community. To assess this approach previously unpublished data (Pettersen, R.A.) were used to compare the number of G. aphyae, G. magnificus, and G. macronychus on the caudal fin with the number of specimen on the total body (using protocol developed by Buchmann, [46]). The results showed that the correlation was strong (Spearman $\rho=0.871, p=0.0001$. Nfish $=73$ ).

Each fin was inspected using a stereomicroscope (40X) to count the number of Gyrodactylus spp. individuals. All Gyrodactylus spp. individuals were carefully removed for preparation for species identification using light microscopy. However, three individuals were lost during the preparation procedures.

Each Gyrodactylus individual was identified to species based on the haptoral hard parts [47]. The haptoral hard parts were digested with Proteinase K (1\% in buffer) until all the tissue was removed, and were mounted on a microscope slide in formaldehyde-glycerine (15:85) fixative. A Leica DM 4000 B microscope with a Heine phase contrast condenser, and a $100 \mathrm{X} / 1.25$ oil immersion 


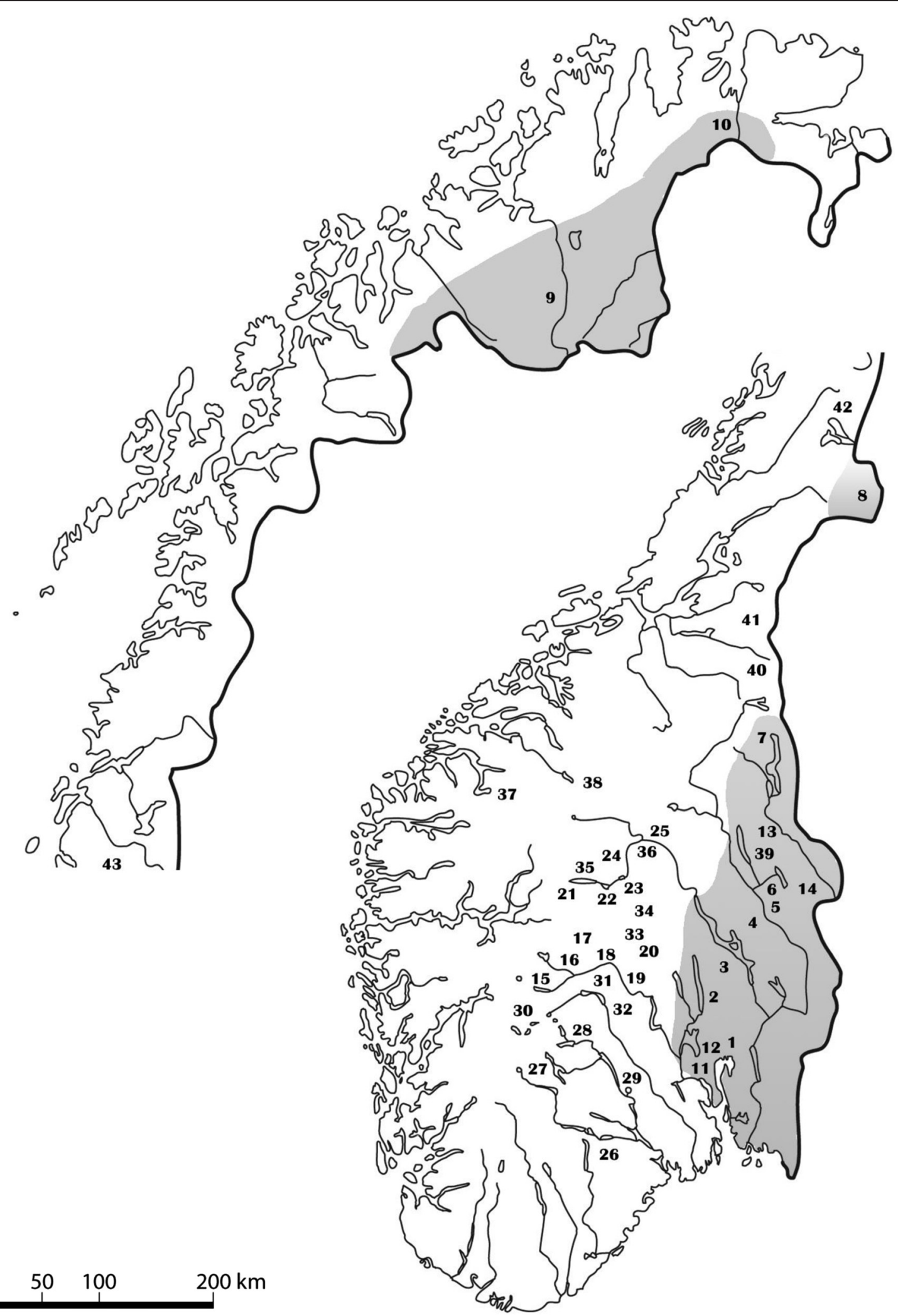

Fig. 1 Sampling locations in Norway. The 43 minnow sampling locations in Norway (see Table 1). The 11 native minnow populations were collected from the grey part of the map 
Table 1 Summary information for the sampled minnow Phoxinus phoxinus populations (11 native and 29 introduced; location number refers to Fig. 1). Location name, river name, sample size of minnow, number of minnows infected with Gyrodactylus spp., and infection intensity (summed number of Gyrodactylus spp.) in the population are given. Three measures of mean population specific genetic variability are also given: heterozygosity, gene diversity and allelic richness (with standard deviations)

\begin{tabular}{|c|c|c|c|c|c|c|c|c|}
\hline $\begin{array}{l}\text { Location } \\
\text { number }\end{array}$ & \multicolumn{2}{|l|}{ Name } & $N$ fish & $\begin{array}{l}\text { Infected } \\
\text { fish }\end{array}$ & $\begin{array}{l}\text { Gyrodactylus ssp. } \\
\text { summed individuals }\end{array}$ & $\begin{array}{l}\text { Heterozygosity } \\
\text { (SD) }\end{array}$ & $\begin{array}{l}\text { Gene diversity } \\
\text { (SD) }\end{array}$ & $\begin{array}{l}\text { Allelic richness } \\
\text { (SD) }\end{array}$ \\
\hline \multicolumn{9}{|l|}{ Native } \\
\hline $1^{*}$ & Sørkedalselva & Lysaker & 55 & 17 & 41 & $0.514(0.115)$ & $0.527(0.370)$ & $1.527(0.355)$ \\
\hline $2^{*}$ & Fallselva & Drammen & 41 & 9 & 14 & $0.603(0.093)$ & $0.567(0.386)$ & $1.567(0.356)$ \\
\hline $3^{*}$ & Hunnselva & Glomma & 45 & 11 & 19 & $0.578(0.112)$ & $0.585(0.340)$ & $1.585(0.294)$ \\
\hline $4^{*}$ & Elverum & Glomma & 18 & 13 & 27 & $0.605(0.156)$ & $0.675(0.356)$ & $1.673(0.291)$ \\
\hline $5^{*}$ & Julussa & Glomma & 10 & 10 & 28 & $0.532(0.107)$ & $0.604(0.362)$ & $1.600(0.321)$ \\
\hline $6^{*}$ & Søre Osa & Glomma & 20 & 10 & 12 & $0.564(0.132)$ & $0.598(0.356)$ & $1.596(0.312)$ \\
\hline $7^{*}$ & Femunden & Trysil & 22 & 8 & 11 & $0.536(0.111)$ & $0.618(0.343)$ & $1.616(0.289)$ \\
\hline $8^{*}$ & Sørli & Sørli & 19 & 10 & 16 & $0.472(0.103)$ & $0.500(0.351)$ & $1.499(0.327)$ \\
\hline $9^{*}$ & Stuorajavri & Alta & 21 & 10 & 35 & $0.621(0.186)$ & $0.592(0.371)$ & $1.590(0.348)$ \\
\hline $10^{*}$ & Tana & Tana & 25 & 6 & 7 & $0.579(0.161)$ & $0.594(0.348)$ & $1.594(0.302)$ \\
\hline 11 & Asdøltjern & Lier & 40 & 0 & 0 & $0.509(0.120)$ & $0.533(0.369)$ & $1.532(0.342)$ \\
\hline 12 & Sagelva & Åros & 54 & 1 & 1 & $0.474(0.114)$ & $0.481(0.369)$ & $1.481(0.351)$ \\
\hline 13 & Fiskebekktjern & Trysil & 20 & 0 & 0 & $0.525(0.178)$ & $0.582(0.344)$ & $1.580(0.301)$ \\
\hline 14 & Landsjøen & Trysil & 17 & 0 & 0 & $0.503(0.148)$ & $0.564(0.338)$ & $1.561(0.297)$ \\
\hline \multicolumn{9}{|c|}{ Introduced } \\
\hline $15^{*}$ & $\varnothing$ Ørteren & Hallingdal & 20 & 5 & 11 & $0.522(0.092)$ & $0.544(0.367)$ & $1.543(0.336)$ \\
\hline $16^{*}$ & Strandavatn & Hallingdal & 33 & 14 & 32 & $0.575(0.119)$ & $0.566(0.341)$ & $1.566(0.300)$ \\
\hline $17^{*}$ & Stolsvatnet & Hallingdal & 60 & 35 & 129 & $0.526(0.118)$ & $0.582(0.330)$ & $1.581(0.282)$ \\
\hline $18^{*}$ & Hustjern & Hallingdal & 16 & 5 & 6 & $0.514(0.123)$ & $0.485(0.355)$ & $1.486(0.334)$ \\
\hline $19^{*}$ & Hallingsdalselva & Hallingdal & 22 & 10 & 18 & $0.517(0.090)$ & $0.560(0.379)$ & $1.559(0.348)$ \\
\hline $20^{*}$ & Tisleia & Begna & 40 & 15 & 36 & $0.567(0.113)$ & $0.577(0.300)$ & $1.578(0.243)$ \\
\hline $21^{*}$ & Bygdin & Vinstra & 36 & 5 & 6 & $0.468(0.120)$ & $0.484(0.340)$ & $1.484(0.315)$ \\
\hline $22^{*}$ & Vinstri & Vinstra & 28 & 18 & 20 & $0.545(0.113)$ & $0.576(0.290)$ & $1.575(0.231)$ \\
\hline $23^{*}$ & Vinstervatna $\varnothing$ & Vinstra & 122 & 11 & 14 & $0.599(0.129)$ & $0.606(0.294)$ & $1.606(0.232)$ \\
\hline $24^{*}$ & Birisjøen & Sjoa & 21 & 10 & 12 & $0.632(0.098)$ & $0.555(0.315)$ & $1.557(0.270)$ \\
\hline $25^{*}$ & Otta & Otta & 8 & 8 & 21 & $0.477(0.118)$ & $0.534(0.371)$ & $1.530(0.342)$ \\
\hline 26 & Mjåvatn & Tovdal & 18 & 0 & 0 & $0.495(0.148)$ & $0.516(0.332)$ & $1.515(0.299)$ \\
\hline 27 & Totak & Skien & 20 & 1 & 1 & $0.514(0.090)$ & $0.499(0.385)$ & $1.500(0.367)$ \\
\hline 28 & Møsvatn & Skien & 17 & 0 & 0 & $0.381(0.134)$ & $0.489(0.332)$ & $1.477(0.295)$ \\
\hline 20 & Follsjå & Skien & 15 & 0 & 0 & $0.409(0.163)$ & $0.453(0.367)$ & $1.449(0.351)$ \\
\hline 30 & Stigstuv & Numedal & 52 & 0 & 0 & $0.515(0.117)$ & $0.536(0.333)$ & $1.536(0.296)$ \\
\hline 31 & Lægreid & Hallingdal & 54 & 0 & 0 & $0.549(0.111)$ & $0.576(0.346)$ & $1.576(0.303)$ \\
\hline 32 & Tunhovd & Numedal & 33 & 1 & 1 & $0.529(0.098)$ & $0.536(0.379)$ & $1.536(0.353)$ \\
\hline 33 & Kippesjøen & Etna & 17 & 0 & 0 & $0.526(0.134)$ & $0.509(0.357)$ & $1.509(0.343)$ \\
\hline 34 & Heggefjorden & Begna & 25 & 4 & 4 & $0.559(0.135)$ & $0.563(0.338)$ & $1.564(0.297)$ \\
\hline 35 & Vinstrervana V & Vinstra & 44 & 0 & 0 & $0.545(0.117)$ & $0.586(0.292)$ & $1.585(0.230)$ \\
\hline 36 & Grovi & Otta & 20 & 1 & 1 & $0.464(0.065)$ & $0.496(0.418)$ & $1.495(0.405)$ \\
\hline 37 & Jølstervatn & Jølster & 38 & 0 & 0 & $0.501(0.102)$ & $0.505(0.373)$ & $1.505(0.352)$ \\
\hline 38 & Lesjaskogsvatn & Gubransdal & 16 & 2 & 2 & $0.577(0.102)$ & $0.580(0.323)$ & $1.579(0.273)$ \\
\hline 39 & Glasåtjhern & Glomma & 10 & 0 & 0 & 0.677 (0.115) & $0.620(0.365)$ & 1.619 (0.315) \\
\hline
\end{tabular}


Table 1 Summary information for the sampled minnow Phoxinus phoxinus populations (11 native and 29 introduced; location number refers to Fig. 1). Location name, river name, sample size of minnow, number of minnows infected with Gyrodactylus spp., and infection intensity (summed number of Gyrodactylus spp.) in the population are given. Three measures of mean population specific genetic variability are also given: heterozygosity, gene diversity and allelic richness (with standard deviations) (Continued)

\begin{tabular}{lllllllll}
\hline 40 & Essandsjøen & Nea & 30 & 3 & 3 & $0.441(0.128)$ & $0.540(0.391)$ & $1.538(0.365)$ \\
41 & Risvatnet & Inna & 20 & 0 & 0 & $0.409(0.099)$ & $0.442(0.396)$ & $1.441(0.387)$ \\
42 & Limingen & Namsen & 20 & 0 & 0 & $0.595(0.095)$ & $0.586(0.339)$ & $1.586(0.294)$ \\
43 & Store Majavatn & Vefsna & 16 & 0 & 0 & $0.419(0.061)$ & $0.421(0.393)$ & $1.422(0.388)$ \\
\hline
\end{tabular}

*Samples used in the rarefaction analysis using EstimateS 8.2 .0 (Colwell 2011) where more than 5 Gyrodactylus spp. individuals were observed in the population. This number of observed Gyrodactylus spp. individuals is needed to calculate rarefaction using the software EstimateS 8.2.0.

objective (no. 506159) was used. This equipment was linked to a Leica DFC 320 digital camera and archiving system, and the Leica software $\mathrm{LAS}_{\odot}$ to take pictures. These pictures were used to identify the different Gyrodactylus species. To establish the identity of the different Gyrodactylus species we used information from the first description and follow-up descriptive literature [9, 48]. We also used an additional visual identification as recommended by Shinn et al. [49] comparing our samples with pictures from the database GyroDb [22]. Five species of Gyrodactylus have previously been reported on minnow from Norway: G. laevis, Malmberg 1957, G. magnificus, Malmberg 1957, G. phoxini, Malmberg 1957, G. macronychus, Malmberg 1957, G. aphyae, Malmberg 1957 [50]. A further nine Gyrodactylus species are reported on minnow elsewhere in Eurasia [22]. One of the authors (Pettersen, R. A.) first identified all the Gyrodactylus species and counted all individuals, while another (Mo, T. A.) checked and confirmed all the species identifications.

\section{Genetic diversity in the minnow hosts}

Neutral multilocus genetic diversity for the minnow hosts was assessed by genotyping 11 microsatellites for a total of 1278 minnows. The 11 microsatellites were selected from a set of 36 microsatellite markers developed for cyprinids (the markers codes are: Z7634, Ca1, Ca3, Ca5, Ca6, Ca12, MFW1, MFW17, GF11, Z15751, Z9692) $[17,51]$. Here, individual and population level heterozygosity were estimated using GenAlEx 6.5 [52], while gene diversity and allelic richness was estimated for populations using Fstat 2.9.3.2. [53]. Population estimates of these three measures of genetic diversity are given in Table 1. We used estimated hetereozygosity as a covariate in the statistical analyses, as Chapman et al., [38] suggests that this is a robust measure of genetic diversity. It is also assumed that heterozygosity is positively associated with parasite resistance (e.g. Blanchet et al., [39]).

To test for hierarchical population structure between native and introduced minnows, as well as for a geographical pattern of population subdivision, analysis of molecular variance (MANOVA, [54]) in the program
GenAlex 6.5 was used [55]. Genetic variance (based on $\left.\phi_{\mathrm{PT}}\right)$ was partitioned among minnow individuals within populations, among populations, and among the population types (native and introduced minnows) using 9999 permutations.

If heterozygosity is important for individual parasite resistance in minnow hosts, demographic population bottlenecks associated with transfer of minnow to new locations may be important. To test for heterozygosity excess, being a signal of a population bottleneck, the Bottleneck 1.2.0.2 software was used [56]. Here, results were evaluated based on the two-phase model (TPM) in the Wilcoxon sign-rank test (1000 iterations), and the "mode - shift" indicator, which discriminates bottlenecked populations from demographically stable populations [57].

After introduction of minnows to new locations a demographic population expansion may occur, which can potentially be linked to persistence against parasites. To test for a demographic population expansion event in the introduced minnow population, we used the kgtest under a stepwise mutation model (SMM) [58]. Here, the k-test compares intra-locus allelic distributions between expanding and stable populations, while the interlocus g-test compares variance in number of repeats between expanding and stable population [58, 59]. A significant number of negative $\mathrm{k}$-values indicate a signature of a demographic population expansion. The g-test significance level was compared to the recommended cutoff value in Table 1 (p. 455) in Reich et al., [58].

\section{Statistical analyses}

In a number of populations we did not find any individual minnows infected with Gyrodactylus spp. To test if the probability of being infected with Gyrodactylus spp. differed between native and introduced minnow populations, we used a nominal logistic regression (binomial distribution, logit link, the distribution of Gyrodactylus spp. is given in Online Resource 1). Presence or absence of Gyrodactylus spp. was used as the response variable, population group (native or introduced) as factor, and average heterozygosity as a covariate. Here, all Gyrodactylus 
species were pooled (43 minnow populations; 1278 fish individuals).

Further, Gyrodactylus species accumulation curves were calculated for each of the native and introduced minnow groups using EstimateS 8.2.0 [60]. This is a sample-based rarefaction curve that gives species accumulation as a function of occurrence, presenting associated $95 \%$ confidence intervals. These curves allow species richness comparisons among test groups, while accounting for differences between locations in the number of individual minnows sampled [61, 62]. Here, only 10 native and 11 introduced populations out of the original 44 populations (Table 1) were used since the sample size of Gyrodactylus specimens in each population must be larger than the total number of Gyrodactylus species observed in the total dataset [60]. Thus, in all the 21 selected minnow populations more than four Gyrodactylus specimens was observed.

The mean number of Gyrodactylus specimens per host was estimated for native and introduced minnow populations, using the minnow populations where Gyrodactylus spp. were observed (29 populations, 880 individuals). We used a generalized linear model with the number of Gyrodactylus specimens as a response variable (using a Poisson error distribution and a log-link, using a maximum likelihood estimation method), and native or introduced minnow populations, population identity nested under the two groups, heterozygosity, and interaction between heterozygosity and native or introduced population groups as factors (interaction was not significant and thus removed from further analyses).

The same statistical test was applied but only using minnow hosts that were infected comprising 21 populations and 253 minnow hosts. Here, again the interaction between heterozygosity and the native or introduced population groups as factors was not significant and subsequently removed from the analyses.

All the statistical analyses, except the rarefaction analyses, were implemented in JMP 9.0 (SAS, 2012) [63].

\section{Results}

\section{Gyrodactylus species occurrence}

A total of 515 Gyrodactylus specimens were examined and identified. Four species were found: G. magnificus, G. phoxini, G. macronychus, and G. aphyae (Table 2). G. aphyae was the most common species being present in all the 21 infected minnow populations. G. magnificus was found in 12 populations, G. macronychus in 10 populations. G. phoxini was only found in 3 minnow populations. Most commonly, only one species of Gyrodactylus was found on each minnow, rarely two species of Gyrodactylus were found on the same tail fin. The combination of G. aphyae and G. magnificus was the most common, being detected on 11 minnows (from 10 populations). The combination of $G$. aphyae and G. phoxini was detected on 3 minnows (from 3 populations), and one minnow had the combination of G. magnificus, and G. macronychus.

\section{Genetic variation and demographic tests in minnow populations}

A total of 1278 minnows were genotyped for 11 microsatellites, and the observed individual level of heterozygosity ranged between 0.091 and 1.0, with the overall mean 0.534 for all fish. The population level heterozygosity ( $\mathrm{N}=43$ populations) ranged from 0.381 (Møsvatn) to 0.632 (Birisjøen). Gene diversity ranged from 0.421 to 0.675 , and allelic richness ranged from 1.422 to 1.673 (Table 1). Based on the MANOVA analysis the genetic variance was partitioned with $77.7 \%$ among individuals within the population level, $21.7 \%$ at the population level and $0.6 \%$ at the among group level (native and introduced) (Table 3). None of the populations showed a significant signal of a bottleneck event (The results are given in Additional file 2). Based on the population expansion analyses ( $\mathrm{k}$ and g-tests), there were no significant signals of demographic expansion in any of the sampled populations (Additional file 2).

\section{Gyrodactylus species diversity and prevalence}

Out of the 43 surveyed populations, 15 minnow populations were not infected with Gyrodactylus spp. (3 native and 12 introduced), while 28 minnow populations had at least one or more hosts infected by one or more Gyrodactylus spp. specimens. A total of 253 individuals in the samples were infected with at least one Gyrodactylus sp. The overall prevalence (i.e. the proportion of individual minnows infected with one or more Gyrodactylus spp. in a given population) ranged between 0 and $100 \%$. The prevalence did not differ between native and introduced minnows $\left(\chi_{1}^{2}=4.252, P=0.119\right)$, and there was no effect of average heterozygosity $\left(\chi_{42}^{2}=2.518, P=0.113\right)$.

The number of Gyrodactylus species did not differ on minnows classified as belonging to either native or introduced populations (tested using EstimateS; $x_{1}^{2}=$ $0.029, P=0.865)$. The diversity varied from 1 to 4 Gyrodactylus species per populations, and the predicted mean number of Gyrodactylus species was 4 species both in the native (95\% confidence interval: 3.9-4.1) and the introduced populations (3.8-4.2).

The intensity of Gyrodactylus spp. per individual minnow host ranged between 1 and 19 (see Additional file 3). When using all the 29 infected populations ( 880 minnows in total) it was found that the mean number of Gyrodactylus individuals (all species) per host differed significantly between the native $(0.64 \pm 1.34$, mean $\pm S D)$ and introduced $(0.35 \pm 1.58)$ minnow groups (whole model: $\chi_{28}^{2}=553.4, P<0.0001$ ), where 
Table 2 The number of minnows from native and introduced populations infected with G. aphyae, G. macronycus, G. magnificus, G. phoxini. For population numbers se Fig. 1

\begin{tabular}{|c|c|c|c|c|c|c|}
\hline \multirow[t]{2}{*}{ Population number } & \multirow[t]{2}{*}{ Location } & \multirow[b]{2}{*}{$N$ fish } & \multicolumn{3}{|c|}{ Number of minnows infected with } & \multirow[b]{2}{*}{ G. phoxin } \\
\hline & & & G. aphyae & G. macronycus & G. magnificus & \\
\hline \multicolumn{7}{|l|}{ Native populations } \\
\hline 1 & Sørkedalselva & 55 & 9 & 5 & 6 & - \\
\hline 2 & Fallselva & 41 & 9 & - & - & - \\
\hline 3 & Hunnselva & 45 & 8 & 5 & - & - \\
\hline 4 & Elverum & 18 & 13 & - & - & - \\
\hline 5 & Julussa & 10 & 2 & 1 & 10 & - \\
\hline 6 & Søre Osa & 20 & 1 & 2 & 7 & - \\
\hline 7 & Femunden & 22 & 4 & 5 & - & - \\
\hline 8 & Sørli & 19 & 6 & 3 & 3 & - \\
\hline 9 & Stuorajavri & 21 & 3 & - & 1 & 8 \\
\hline 10 & Tana & 25 & 1 & 5 & - & - \\
\hline \multicolumn{7}{|c|}{ Introduced populations } \\
\hline 16 & Ørteren & 20 & 5 & - & - & 1 \\
\hline 17 & Strandavatn & 33 & 1 & - & 14 & - \\
\hline 18 & Stolsvatnet & 60 & 35 & 2 & 5 & 2 \\
\hline 19 & Hustjern & 16 & 5 & - & - & - \\
\hline 20 & Hallingdalselva & 22 & 1 & - & 9 & - \\
\hline 21 & Tisleia & 40 & 3 & - & 12 & - \\
\hline 22 & Bygdin & 36 & 2 & - & 4 & - \\
\hline 23 & Vinstri & 28 & 11 & 7 & 1 & - \\
\hline 24 & Vinstervanta $\varnothing$ & 122 & 5 & 6 & 2 & - \\
\hline 25 & Birisjøen & 21 & 10 & - & - & - \\
\hline 26 & Otta & 8 & 8 & - & - & - \\
\hline
\end{tabular}

the introduced group had a lower infection (Table 4). The abundance was significantly negatively associated with individual heterozygosity, and there was no interaction effect (Table 4).

\section{Discussion}

The "enemy release hypothesis" suggests that introduced species should harbour fewer parasite species than native species. The observed results do not support the enemy release hypothesis as similar numbers of Gyrodactylus species were observed on native and introduced minnow hosts, and they had the same likelihood of being infected with Gyrodactylus spp. In support of the observed results, Daverdin [64] compared some native minnow populations to an introduced minnow population (one of the lakes in our study) and observed no difference in the internal parasite fauna showing that the same fauna was established in the new environment. The same result was found in a study of the common carp (Cyprinus carpio L.) where there were no differences in helminth communities between native and introduced populations [65]. Several other studies have found some support for the enemy release hypothesis spanning a range of organisms including freshwater fish $[29,31,33,66,67]$. However, the success of

Table 3 Analysis of molecular variance (AMOVA) based on 11 microsatellites for the 43 minnow populations. The two groups are defined by 29 introduced and 14 native minnow populations. Variance is partitioned among the groups, among populations and within populations using random permutations

\begin{tabular}{lcllrr}
\hline Variance component & Sum of squares & Degrees of freedom & \% total & Variance & $P$ value \\
\hline Among groups & 116.71 & 1 & 0.55 & 0.06 & $<0.0001$ \\
Among population & 2713.86 & 41 & 21.70 & 2.02 & $<0.0001$ \\
Within population & 8937.14 & 1235 & 77.71 & 7.24 & $<0.0001$ \\
Total & 11767.74 & 1277 & & 9.31 & $<0.0001$ \\
\hline
\end{tabular}


Table 4 Summary result from the generalized linear model on number of Gyrodactylus spp. Individuals per minnow host, with population group (native or introduced minnow populations) as factor and individual minnow heterozygosity as covariate. Population identity was nested under population group. In this test we only used the infected populations (29 populations, 880 individuals)

\begin{tabular}{lcll}
\hline Factores & Sum of squares & Degrees of freedom & $p$ \\
\hline Among groups & 8.84 & 1 & 0.003 \\
Populations nested in groups & 545.15 & 26 & $<0.0001$ \\
Heterozygosity & 10.69 & 1 & 0.001 \\
\hline
\end{tabular}

parasite species introductions will likely depend on the complexity of the parasite lifecycle. Parasites with a lifecycle that requires more than one host will likely have a lower probability of introduction and establishment in a new environment [68] than parasites with a direct lifecycle (no intermediate hosts).

An alternative to the enemy release hypothesis is that the number of Gyrodactylus species increase in the introduced populations due to transmission of new Gyrodactylus species from other fish species already present in the new environment. However, this seems unlikely in the case of the minnow as most Gyrodactylus species seem to be host specific [22]. Further, it is possible that abiotic environmental conditions are also important factors determining species numbers [35]. Thus, if the environmental conditions differ strongly also the parasite fauna may differ. Environmental conditions are usually more similar for geographically close locations. Also, multiple introductions from the same source population would likely ensure that the whole parasite species fauna would be found in both environments. Thaulow et al. [18] have shown that multiple introductions of minnows have occurred from different sources into one of the same river systems studied here (River Skiensvassdraget). Thus, it is possible that multiple introduction events of minnows into lakes in this study could partly explain the similarity of the Gyrodactylus species fauna we observed in native and introduced minnows.

The abundance of Gyrodactylus was observed to be lower in introduced minnow compared to native populations in this study. This seems at odds with the enemyrelease hypothesis. However, the enemy-releasehypothesis may be imprecise as it usually only considers presence or absence of parasite species. The parasite species-specific abundance of hosts is not taken into account. It is reasonable to assume that the more diverse parasite species infection a host has, as well as the abundance of each species, the higher challenge will be imposed on the immune system of the host [69]. Torchin et al. [29], who studied introduced and native populations of a set of diverse organisms observed that the mean number of parasite individuals within parasite species were lower in introduced than in native populations, similar to our observation of Gyrodactylus on the minnows.
Most of the studies that test the enemy release hypothesis do not have data on individual heterozygosity. In this study, we found no significant association between mean heterozygosity and the probability of being infected with Gyrodactylus (absence versus presence of infection) when using the whole dataset. However, when using only infected minnow there was a significant negative association between individual heterozygosity and mean number of Gyrodactylus. Here, the association of a higher Gyrodactylus infection level in more homozygotic minnow hosts was found for both native and introduced populations. This may indicate that more diverse hosts are better able to combat the infections. In two studies on the rostrum dace (Leuciscus leuciscus L.), Blanchet et al., $[39,70]$ tested if heterozygosity was associated with the mean number of the harmful fin-feeder ectoparasite Tracheliastes polycolpus Nordmann, 1832. They observed that parasite burdens were highest in hosts being moderately heterozygous, while extremely homozygous and heterozygous hosts had a lower parasite burden. This result seems in conflict with our observations for the minnow-Gyrodactylus system. However, this apparent conflict may be caused by different ranges of genetic variation among hosts in the various studies.

It is likely that the number of founder populations differ between native and introduced minnow populations. Also, the degree of heterozygosity may be associated with the success of founder populations [71]. However, the lack of significant bottleneck signals in the minnow populations suggested that no drastic decrease in genetic diversity occurred during colonization events (although the power of the test may be weak; see $[57,72])$. This is also supported by the results from the AMOVA analysis, showing that only $0.6 \%$ of the genetic variation was partitioned between the native and introduced populations. Thus, the relatively high level of genetic variation in the introduced populations could help explain that the two groups had the same number of Gyrodactylus species observed (from species accumulation curves). This evaluation is valid under the assumption that similar levels of heterozygosity reflects similar abilities to withstand negative impacts from Gyrodactylus spp. infection, and that heterozygosity based on neutral microsatellites is correlated to genetic variation in e.g. adaptive 
immunocompetence genes ( $\mathrm{MHC})$ associated to parasite resistance $[40,73]$.

\section{Geographical distribution of Gyrodactylus spp. on minnows}

In order to place the findings of this study in a biogeographical framework we here report on the distribution of Gyrodactylus spp. in Norway and other parts of Europe. A total of fourteen species of Gyrodactylus have been described on minnow on a global scale [22]. In this study, a total of four out of five previously reported Gyrodactylus species in Norway [50] were observed in the 43 minnow populations. To the southeast, in Sweden, two more Gyrodactylus species have been found on minnow [9]. The most plausible explanation for why Norway has a lower number of Gyrodactylus species than the rest of Europe is Norway`s relatively recent deglaciation ( $<10000$ years ago) and location to the west on the Scandinavian peninsula, with relatively long colonization routes from assumed glacial refugia. For minnows these refugia are probably situated in south central Europe (based on species determination of dated bones from the Eem interglacial (ca .150 000 years before present) [74], and likely also somewhere in Russia. Indeed, hosts at the geographical limits of their distribution often have fewer parasites in general or lack species-specific parasites (see [75]). In this study, a maximum of four Gyrodactylus species was observed in a minnow population. This finding is not too different from other European studies, in which a maximum of six Gyrodactylus species have been found in a single minnow population $[19,20]$. In the current study, $G$. aphyae was found in all populations, while the three other species were more or less rare. G. phoxini was found in only three locations, detected on a few hosts only. The two most common species (G. aphyae and G. macronychus) in this study were also the most common species reported in the literature on Gyrodactylus on European minnow [19, 20]. Most commonly, only one Gyrodactylus species, rarely two, was observed on the individual hosts. If two species co-occurred, the combination of G. aphyae and G. magnificus was the most commonly observed.

The environmental conditions in a given lake may likely affect the establishment of the hosts in the new environments, as well as being important for survival and demographics of Gyrodactylus on hosts [76-79]. In this study, this could influence the mean number of Gyrodactylus as lakes are situated at different altitudes and thus comprise a range of environmental regimes for Gyrodactylus spp. Further, introduced minnow populations may need to be of a certain size in order to uphold a viable population of Gyrodactylus [80]. Also the population density and behaviour of minnows in a new location may be important with regard to horizontal transmission and population dynamics of Gyrodactylus [81].

Physio-chemical conditions of the lake environment could affect the success of establishment of minnows and its parasite fauna during introduction to new environments. Such factors could be e.g. $\mathrm{pH}$ and water temperature as these factors have been shown to be associated with Gyrodactylus spp. development and survival [77-79]. In our study, this could influence the results as lakes are situated at different altitudes and thus comprise differential temperature regimes for Gyrodactylus spp. However, the wide geographic range covered by both native and non-native populations suggests that such abiotic drivers do not significantly bias the results.

\section{Conclusions}

In this study it was observed that native and introduced minnow populations did not differ in their species community of Gyrodactylus spp., which lends no support to the enemy release hypothesis. However, the average number of parasites per host was higher in the native than in the introduced minnow. Interestingly, a negative association between individual minnow host heterozygosity and abundance was detected, being evident in both the native and introduced minnow populations. Our results suggest that the enemy release hypothesis does not necessarily limit fish parasite dispersal, further emphasizing the importance of invasive fish species dispersal control.

\section{Additional files}

Additional file 1: Table S1. A table of other fish species in the sampled localities. All the Norwegian minnow (Phoxinus phoxinus) populations used in the study and the other fish species in the same locality. The species of fish are: $\mathrm{AC}=$ Arctic charr (Salvelinus alpinus) $\mathrm{BL}=$ bleak (Alburnus alburnus), BR = bream (Abramis brama), BT = brown trout (Salmo trutta), BU = burbot (Lota lota), CC = crucian carp (Carassius carassius), $\mathrm{CH}=$ chub (Leuciscus cephalus), $\mathrm{EE}=$ eel (Anguilla anguilla), GR = grayling (Thymallus thymallus), PE = perch (Perca fluviatilis), PI = pike (Esox lucius), $\mathrm{RU}=$ ruffe (Gymnocephalus cernuus), SS = Siberian sculpin (Cottus poecilopus), $\mathrm{VE}=$ vendace (Coregonus albula), WB = white bream (Blicca bjoerkna), WF = European whitefish, $\mathrm{SM}=$ smelt (Osmerus eperlanus), $\mathrm{ID}=$ ide (Leuciscus idus), DA = dace (Leuciscus leuciscus), 9-SB = ninespined stickleback (Pungitius pungitius) and $3-\mathrm{SB}=$ tree-spined stickleback (Gasterosteus aculeatus). (DOC $192 \mathrm{~kb}$ )

Additional file 2: A table of tests result of demographic bottleneck. All the Norwegian minnow (Phoxinus phoxinus) populations used in the study. Information from tests of demographic bottleneck using Bottleneck 1.2.0.2. (Piry et al. 1999) with the two-phase model (TPM) and the Wilcoxon sign-rank test, and demographic expansion (where the intra-locus k-test identify signals of recent population expansion, while the inter-locus g-test identify signals of more ancient population expansion) using Kg-test (Reich et al. 1999). Footnotes: *Samples used in the rarefaction analysis using EstimateS 8.2.0 (Colwell 2011) where more than 5 Gyrodactylus spp. individuals were observed in the population. This number of observed 
Gyrodactylus spp individuals is needed to calculate rarefaction in EstimateS 8.2.0. \# None of tests were significant. (DOC $116 \mathrm{~kb}$ )

\section{Additional file 3: Figure of distribution of Gyrodactylus spp.}

individuals. Distribution of Gyrodactylus spp. individuals in the total dataset of 1278 individual minnows (Phoxinus phoxinus) hosts from 43 populations in Norway. Here the 14 native and 23 stocked populations have been pooled. On the left axis is the probability of occurrence and on right axis is given counts. (DOCX $76 \mathrm{~kb}$ )

\section{Competing interests}

The authors declare that they have no competing interests.

\section{Authors' contributions}

RAP, $K \varnothing, J H, L A V$ and TAM, designed the study. JH collected the minnow. RAP and $J H$ performed data collection. RAP, KØ, JH and LAV analysed the results. RAP, $K \varnothing, J H, L A V$ and TAM co-drafted the manuscript together. All authors read and approved the final version of the manuscript.

\section{Acknowledgements}

First of all, we want to thank all the people who sampled minnow for us. We further thank Nanna Winger Steen and Emelita Rivera Nerli for technical assistance in the laboratory. The collection of fish and genotyping was financially supported by grants from the Norwegian Research Council, the Norwegian Environment Agency and the Finnish Academy.

\section{Author details}

${ }^{1}$ Center for Ecological and Evolutionary Synthesis (CEES), Department of Biosciences, University of Oslo, P. O. Box 1066 Blindern, NO-0316, Oslo, Norway. ${ }^{2}$ Department of Forestry and Wildlife Management, Hedmark University College, Campus Evenstad, Elverum, NO 2418, Norway. ${ }^{3}$ Norwegian Veterinary Institute, P.O. Box 8156, Dep. NO-0033, Oslo, Norway.

\section{Received: 12 May 2015 Accepted: 14 January 2016}

\section{Published online: 28 January 2016}

\section{References}

1. Vitousek PM, Mooney HA, Lubchenco J, Melillo JM. Human domination of Earth's ecosystems. Science. 1997:277(5325):494-9.

2. Rahel FJ, Olden JD. Assessing the effects of climate change on aquatic invasive species. Conserv Biol. 2008;22(3):521-33.

3. Gherardi F, Britton JR, Mavuti KM, Pacini N, Grey J, Tricarico E, et al. A review of allodiversity in Lake Naivasha, Kenya: Developing conservation actions to protect East African lakes from the negative impacts of alien species. Biol Conserv. 2011:144(11):2585-96.

4. Hulme PE, Pysek P, Nentwig W, Vila M. Will Threat of Biological Invasions Unite the European Union? Science. 2009:324(5923):40-1.

5. Perrings C, Dehnen-Schmutz K, Touza J, Williamson M. How to manage biological invasions under globalization. Trends Ecol Evol. 2005;20(5):212-5.

6. Pimentel D, Zuniga R, Morrison D. Update on the environmental and economic costs associated with alien-invasive species in the United States. Ecol Econ. 2005;52(3):273-88

7. Peeler EJ, Oidtmann BC, Midtlyng PJ, Miossec L, Gozlan RE. Non-native aquatic animals introductions have driven disease emergence in Europe. Biol Invasions. 2011;13(6):1291-303.

8. Parker IM, Simberloff D, Lonsdale WM, Goodell K, Wonham M, Kareiva PM, et al. Impact: toward a framework for understanding the ecological effects of invaders. Biol Invasions. 1999:1(1):3-19.

9. Malmberg G. Om förekomsten av Gyrodactylus på svenska fiskar. Skrifter utgivna av Söndre Sverges fiskeriförening. 1957;1956:19-76.

10. Johnsen BO, Jensen AJ. The Gyrodactylus story in Norway. Aquaculture. 1991;98(1-3):289-302.

11. Vralstad T, Strand DA, Grandjean F, Kvellestad A, Hastein T, Knutsen AK, et al. Molecular detection and genotyping of Aphanomyces astaci directly from preserved crayfish samples uncovers the Norwegian crayfish plague disease history. Vet Microbiol. 2014;173(1-2):66-75.

12. Pegg J, Williams CF, Cucherousset J, Britton JR. What are the consequences of infection by the introduced parasite Philometroides sanguineus for threatened crucian carp Carassius carassius populations in England? Ecol Freshw Fish. 2011;20(4):598-604.
13. Rahel FJ. Homogenization of fish faunas across the United States. Science. 2000;288(5467):854-6.

14. Rahel FJ. Biogeographic barriers, connectivity and homogenization of freshwater faunas: it's a small world after all. Freshw Biol. 2007:52(4):696-710.

15. Huitfeldt-Kaas. Ferskvandsfiskenes utbredelse og indvandring i Norge, med et tillæg om krebsen. in Norwegian (Distribution and post-glacial colonisation of freshwater fishes in Norway, including the cray fish.). In: Centraltrykkeriet, Kristiania (Oslo). 1918.

16. Museth J, Hesthagen T, Sandlund OT, Thorstad EB, Ugedal O. The history of the minnow Phoxinus phoxinus (L.) in Norway: from harmless species to pest. J Fish Biol. 2007;71:184-95.

17. Holmen J: The Eurasian minnow: post-glacial dispersal history and recent invasion patterns in Norway. Ph.D. thesis: University of Oslo; 2013.

18. Thaulow J, Borgstrøm R, Heun M. Genetic analyses of European minnow, Phoxinus phoxinus, in a river system outside its native range indicate multiple invasions from different sources. Fisheries Manag Ecol. 2014;21(1):75-81.

19. Dorovskikh GN, Stepanov VG. Change in the structure of component parasite communities with host age. Russ J Ecol. 2008;39(3):215-20.

20. Matejusova I, Morand S, Gelnar M. Nestedness in assemblages of gyrodactylids (Monogenea : Gyrodactylidea) parasitising two species of cyprinid - with reference to generalists and specialists. Int J Parasit. 2000;30(11):1153-8.

21. Sterud E: Parasites of Norwegian fresh-water fish. vol. 7. Oslo: Norsk zoologisk forening; 1999: $22 \mathrm{~s}$.

22. Harris PD, Shinn AP, Cable J, Bakke TA, Bron J. GyroDb: gyrodactylid monogeneans on the web. Trends Parasitol. 2008;24(3):109-11.

23. Bakke TA, Cable J, Harris PD. The biology of gyrodactylid monogeneans: The "Russian-doll killers". Adv Parasitol. 2007:64:161-330.

24. Poulin R: Evolutionary ecology of parasites. Second edition. Princeton University: Princeton University Press; 2007

25. Karvonen A, Seehausen O. The Role of Parasitism in Adaptive RadiationsWhen Might Parasites Promote and When Might They Constrain Ecological Speciation? Int J Ecology. 2012;280169:280161-20.

26. Elton CS. The ecology of invasions by animals and plants. London: Methuen;

27. Wilson F. The biological control of weeds. In: Report of the Sixth Commonwealth Entomological Congress, London. 1954. p. 95-8.

28. Mitchell CE, Power AG. Release of invasive plants from fungal and viral pathogens. Nature. 2003;421(6923):625-7.

29. Torchin ME, Lafferty KD, Dobson AP, McKenzie VJ, Kuris AM. Introduced species and their missing parasites. Nature. 2003;421(6923):628-30.

30. Heger T, Jeschke JM. The enemy release hypothesis as a hierarchy of hypotheses. Oikos. 2014;123(6):741-50.

31. Roche DG, Leung B, Franco EFM, Torchin ME. Higher parasite richness, abundance and impact in native versus introduced cichlid fishes. Int Parasit. 2010:40(13):1525-30

32. Ondračková M, Šimková A, Civáňová K, Vyskočilová M, Jurajda P. Parasite diversity and microsatellite variability in native and introduced populations of four Neogobius species (Gobiidae). Parasitology. 2012;139(11):1493-505.

33. Lacerda ACF, Takemoto RM, Tavares-Dias M, Poulin R, Pavanelli GC. Comparative parasitism of the fish Plagioscion squamosissimus in native and invaded river basins. J Parasitol. 2012;98(4):713-7.

34. Gendron AD, Marcogliese DJ, Thomas M. Invasive species are less parasitized than native competitors, but for how long? The case of the round goby in the Great Lakes-St. Lawrence Basin Biol Invasions. 2012:14(2):367-84.

35. Halvorsen O. Studies of the helminth fauna of Norway XVII: On the composition of the parasite fauna of coarse fish in the River Glomma South Eastern Norway. Nor J Zoology. 1971;19(2):181-92.

36. Cornell HV, Hawkins BA. Accumulation of Native Parasitod Species on Introduced Herbivores: A Comparison of Hosts as Native and Hosts as Invaders. Am Nat. 1993:141(6):847-65.

37. Poulin R, Mouillot D. Host introductions and the geography of parasite taxonomic diversity. J Biogeogr. 2003:30(6):837-45.

38. Chapman JR, Nakagawa S, Coltman DW, Slate J, Sheldon BC. A quantitative review of heterozygosity-fitness correlations in animal populations. (vol 18 pg 2746. Mol Ecol 2011. 2009:20(12):2655.

39. Blanchet S, Rey O, Berthier P, Lek S, Loot G. Evidence of parasite-mediated disruptive selection on genetic diversity in a wild fish population. Mol Ecol. 2009:18(6):1112-23. 
40. Collin H, Burri R, Comtesse F, Fumagalli L. Combining molecular evolution and environmental genomics to unravel adaptive processes of $\mathrm{MHC}$ class IIB diversity in European minnows (Phoxinus phoxinus). Ecology and Evolution. 2013;3(8):2568-85.

41. Voegeli B, Saladin V, Wegmann M, Richner H. Parasites as mediators of heterozygosity-fitness correlations in the Great Tit (Parus major). J Evol Biol. 2012;25(3):584-90.

42. Alvarez-Pellitero P. Fish immunity and parasite infections: from innate immunity to immunoprophylactic prospects. Vet Immunol Immunopathol. 2008;126(3-4):171-98.

43. Moran EV, Alexander JM. Evolutionary responses to global change: lessons from invasive species. Ecol Lett. 2014;17(5):637-49.

44. Hesthagen T, Sandlund OT. Fish distribution in a mountain area in southeastern Norway: human introductions overrule natural immigration. Hydrobiologia. 2004:521(1-3):49-59.

45. Hesthagen T, Sandlund OT. Chanfes in the distribution of European minnow, Phoxinus phoxinus, in Norway: causes and effects, vol. 013 Norwegian Institute for Nature Researc: Trondheim; 1997.

46. Buchmann K, Uldal A. Gyrodactylus derjavini infections in four salmonids: Comparative host susceptibility and site selection of parasites. Dis Aquat Org. 1997;28(3):201-9.

47. Mo TA, Appleby C. A special technique for studyng haptoral sclerites of monogeneans. Syst Parasitol. 1990;17(2):103-8.

48. Ziętara MS, Lumme J. The crossroads of molecular, typological and biological species concepts: two new species of Gyrodacty/us Nordmann, 1832 (Monogenea : Gyrodactylidae). Syst Parasitol. 2003;55(1):39-52.

49. Shinn AP, Collins C, Garcia-Vasquez A, Snow M, Matejusova I, Paladini G, et al. Multi-centre testing and validation of current protocols for the identification of Gyrodactylus salaris (Monogenea). Int J Parasit. 2010;40(12):1455-67.

50. Sterud E. Parasitter hos norske ferskvannsfisk. Norsk Zoologisk Forening. 1999;7:1-22.

51. Holmen J, Vøllestad LA, Jakobsen KS, Primmer CR. Cross-species amplification of zebrafish and central stoneroller microsatellite loci in six other cyprinids. J Fish Biol. 2005;66(3):851-9.

52. Peakall R, Smouse PE. GENALEX 6: genetic analysis in Excel. Population genetic software for teaching and research. Mol Ecol Notes. 2006;6(1):288-95.

53. Goudet J. FSTAT (Version 1.2): A computer program to calculate F-statistics. J Hered. 1995:86(6):485-6.

54. Excoffier L, Smouse PE, Quattro JM. Analyse of Molecular Variance Innferred From Metric Distances Among DNA haplotypes: Application to Human Mitochondrial DNA Restriction Data. Genetics. 1992;131(2):479-91.

55. Peakall R, Smouse PE. GenAlEx 6.5: genetic analysis in Excel. Population genetic software for teaching and research-an update. Bioinformatics. 2012;28(19):2537-9.

56. Piry S, Luikart G, Cornuet JM. BOTTLENECK: A computer program for detecting recent reductions in the effective population size using allele frequency data. J Hered. 1999;90(4):502-3.

57. Cornuet JM, Luikart G. Description and power analysis of two tests for detecting recent population bottlenecks from allele frequency data. Genetics. 1996;144(4):2001-14.

58. Reich DE, Feldman MW, Goldstein DB. Statistical properties of two tests that use multilocus data sets to detect population expansions. Mol Biol Evol. 1999:16(4):453-66.

59. Reich DE, Goldstein DB. Genetic evidence for a Paleolithic human population expansion in Africa. Proc Natl Acad Sci U S A. 1998;95(14):8119-23.

60. Colwell R, K.: EstimateS 8.2.0: Statistical estimation of species richness and shared species from samples. User's Guide and application published at: http://viceroy.eeb.uconn.edu/estimates/.

61. Gotelli NJ, Colwell RK. Quantifying biodiversity: procedures and pitfalls in the measurement and comparison of species richness. Ecol Lett. 2001:4(4):379-91.

62. Longino JT, Coddington J, Colwell RK. The ant fauna of a tropical rain forest: Estimating species richness three different ways. Ecology. 2002;83(3):689-702.

63. Sall J, Creighton L, Lehman A. JMP start statistics: a guide to statistics and data analysis using JMP. Cary, N.C.: SAS Pub; 2007.

64. Daverdin $\mathrm{RH}$. Dissemination of parasites through introduction of freshwater fish species: introduction of minnow (Phoxinus phoxinus) parasites to high altitude lakes with brown trout (Salmo trutta), vol. 466. Trondheim: Norwegian Institute for Nature Research; 1997.
65. Kennedy CR, Pojmanska T. Richness and diversity of helminth parasite communities in the common carp and in three more recently introduced carp species. J Fish Biol. 1996;48(1):89-100.

66. Kennedy CR, Hartvigsen R, Halvorsen O. The importance of fish stocking in the dissemination of parasites throughout a group of reservoirs. J Fish Biol. 1991;38(4):541-52.

67. Ondračková M, Matějusová I, Grabowska J. Introduction of Gyrodactylus perccotti (Monogenea) into Europe on its invasive fish host, Amur sleeper (Perccottus glenii, Dybowski 1877). Helminthologia. 2012;49(1):21-6.

68. Bauer ON. Spread of parasites and diseases of aquatic organisms by acclimation - ashort review. J Fish Biol. 1991;39(5):679-86.

69. Zuk M, Stoehr AM. Immune defense and host life history. Am Nat. 2002;160:S9-S22

70. Blanchet S, Rey O, Loot G. Evidence for host variation in parasite tolerance in a wild fish population. Evol Ecol. 2010;24(5):1129-39.

71. Forsman A. Effects of genotypic and phenotypic variation on establishment are important for conservation, invasion, and infection biology. Proc Nat Acad Sci U S A. 2014;111(1):302-7.

72. Peery MZ, Kirby R, Reid BN, Stoelting R, Doucet-Bëer E, Robinson S, et al. Reliability of genetic bottleneck tests for detecting recent population declines. Mol Ecol. 2012;21(14):3403-18.

73. Monzon-Arguello C, de Leaniz CG, Gajardo G, Consuegra S. Ecoimmunology of fish invasions: the role of MHC variation. Immunogenetics. 2014;66(6):393-402

74. Movius HL. Radiocarbon Dates and Upper Palaeolithic Archaeology in Central and Western Europe. Curr Anthropol. 1960;1(5-6):355-91.

75. Dogiel VA: General parasitology. 3rd Edit., revd. Polyanski, Yu. I. \& Khaeisin, E. M., transl. Kabata, Z. (Oliver \& Boyd). Edinburgh 1964.

76. Kennedy CR. Parasite fauna of resident char (Salvelinus alpinus) from Arctic islands, with special reference to Bear Island. J Fish Biol. 1978;13(4):457-66.

77. Marcogliese DJ, Cone DK. On the distribution and abundance of eel parasites in Nova Scotia: Influence of pH. J Parasitologi. 1996;82(3):389-99.

78. Pettersen RA, Vøllestad LA, Flodmark LEW, Poléo ABS. Effects of aqueous aluminium on four fish ectoparasites. Sci Total Environ. 2006;369(1-3):129-38.

79. Poléo ABS, Schjolden J, Hansen H, Bakke TA, Mo TA, Rosseland BO, et al. The effect of various metals on Gyrodactylus salaris (Platyhelminthes, Monogenea) infections in Atlantic salmon (Salmo salar). Parasitology. 2004;128:169-77.

80. Lyles AM, Dobson AP. Infectious disease and intensive management population dynamics, threatened hosts, and their parasites. J Zoo Wildl Med. 1993;24(3):315-26

81. Bernhardt B, Lampert KP, Leese F, Mayer C, Tollrian R. Are shoals of minnow Phoxinus phoxinus formed by close kin? J Fish Biol. 2012:80(3):713-21.

\section{Submit your next manuscript to BioMed Central and we will help you at every step:}

- We accept pre-submission inquiries

- Our selector tool helps you to find the most relevant journal

- We provide round the clock customer support

- Convenient online submission

- Thorough peer review

- Inclusion in PubMed and all major indexing services

- Maximum visibility for your research

Submit your manuscript at www biomedcentral.com/submit
C Biomed Central 